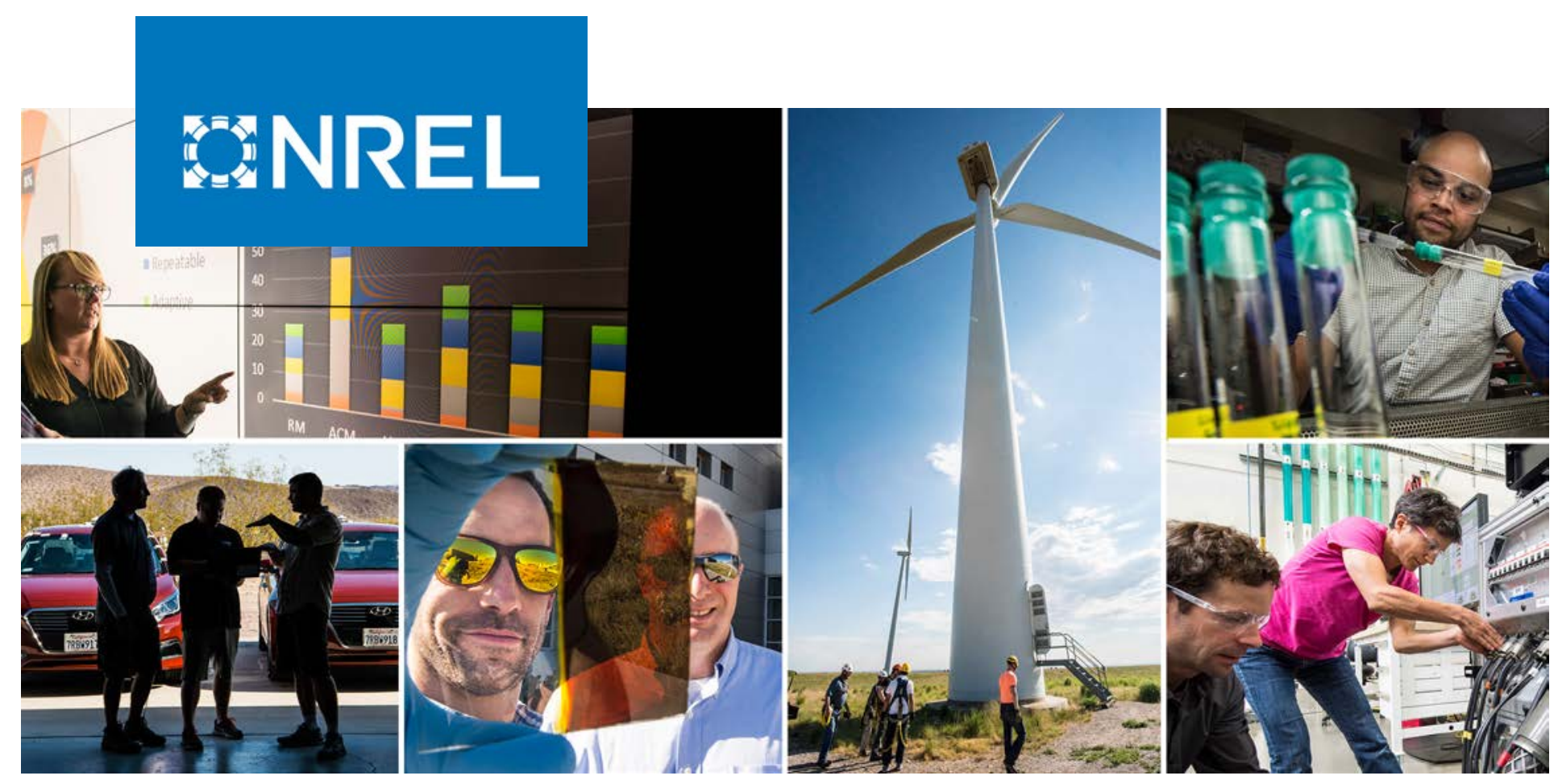

\title{
Design and Implementation of Community Solar Programs for Low- and Moderate-Income Customers
}

Jenny Heeter, Lori Bird, Eric O'Shaughnessy, and Sam Koebrich

National Renewable Energy Laboratory

NREL is a national laboratory of the U.S. Department of Energy

Office of Energy Efficiency \& Renewable Energy

Operated by the Alliance for Sustainable Energy, LLC

This report is available at no cost from the National Renewable Energy Laboratory (NREL) at www.nrel.gov/publications.
Technical Report

NREL/TP-6A20-71652

December 2018 


\title{
GNREL
}

\section{Design and Implementation of Community Solar Programs for Low- and Moderate-Income Customers}

\author{
Jenny Heeter, Lori Bird, Eric O'Shaughnessy, \\ and Sam Koebrich
}

National Renewable Energy Laboratory

\section{Suggested Citation}

Heeter, Jenny, Lori Bird, Eric O'Shaughnessy, and Sam Koebrich. 2018. Design and Implementation of Community Solar Programs for Low- and Moderate-Income Customers. Golden, CO: National Renewable Energy Laboratory. NREL/TP-6A20- 71652.

https://www.nrel.gov/docs/fy19osti/71652.pdf.

NREL is a national laboratory of the U.S. Department of Energy Office of Energy Efficiency \& Renewable Energy Operated by the Alliance for Sustainable Energy, LLC

This report is available at no cost from the National Renewable Energy Laboratory (NREL) at www.nrel.gov/publications.

Contract No. DE-AC36-08G028308
Technical Report

NREL/TP-6A20-71652

December 2018

National Renewable Energy Laboratory 15013 Denver West Parkway Golden, CO 80401

303-275-3000 • www.nrel.gov 


\section{NOTICE}

This work was authored by the National Renewable Energy Laboratory, operated by Alliance for Sustainable Energy, LLC, for the U.S. Department of Energy (DOE) under Contract No. DE-AC36-08GO28308. Funding provided by the U.S. Department of Energy Office of Energy Efficiency and Renewable Energy Solar Energy Technologies Office. The views expressed in the article do not necessarily represent the views of the DOE or the U.S. Government. The U.S. Government retains and the publisher, by accepting the article for publication, acknowledges that the U.S. Government retains a nonexclusive, paid-up, irrevocable, worldwide license to publish or reproduce the published form of this work, or allow others to do so, for U.S. Government purposes.

This report is available at no cost from the National Renewable Energy Laboratory (NREL) at www.nrel.gov/publications.

U.S. Department of Energy (DOE) reports produced after 1991 and a growing number of pre-1991 documents are available free via www.OSTI.gov.

Cover Photos by Dennis Schroeder: (clockwise, left to right) NREL 51934, NREL 45897, NREL 42160, NREL 45891, NREL 48097, NREL 46526.

NREL prints on paper that contains recycled content. 


\section{Acknowledgments}

The authors would like to thank the following individuals for their insights about low- and moderate-income community solar programs:

- Shauna Beland, Rhode Island Office of Energy Resources

- Adrienne Dorsey, GRID Alternatives

- Tom Figel, GRID Alternatives

- Beth Galante, PosiGen

- Brian Granahan, Illinois Power Agency

- Isabelle Hazlewood and Kerry O’Neill, Connecticut Green Bank

- Tom Hunt, Clean Energy Collective

- David Parsons and Matt McDonnell, Hawaii Public Utilities Commission

- Zachary Sippel, Energy Trust of Oregon

- Daniel White and Edward Yim, Washington, D.C. Department of Energy \& Environment.

The authors would also like to thank Kristen Ardani, Jaquelin Cochran, Jeff Cook, and Monisha Shah of the National Renewable Energy Laboratory (NREL), Warren Leon and Diana Chace of the Clean Energy States Alliance, and Shubha Jaishankar of the Department of Energy Solar Energy Technologies Office for their review.

The report was prepared by NREL for the Clean Energy States Alliance and funded by the US Department of Energy Solar Energy Technologies Office, under TSA-16-891, State Strategies to Bring Solar to Low- and Moderate-Income Communities. 


\section{Table of Contents}

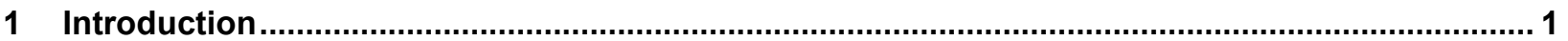

2 Existing and Emerging State LMI Community Solar Programs ............................................... 2

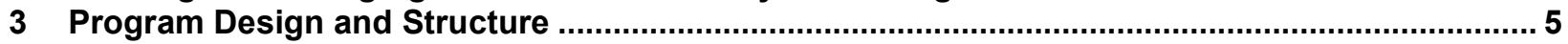

3.1 What is the Optimal Customer Participant Mix? ..................................................................... 5

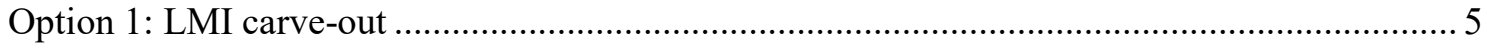

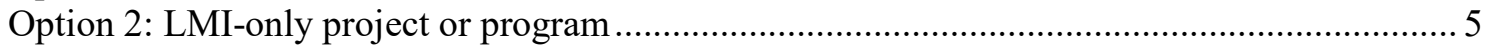

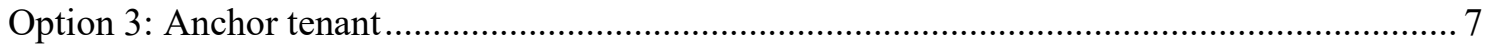

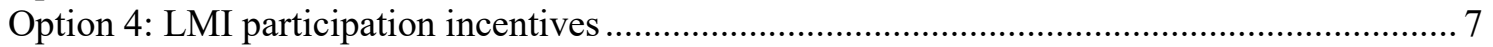

3.2 How are LMI Customers Billed and Credited for their Subscriptions? .................................... 7

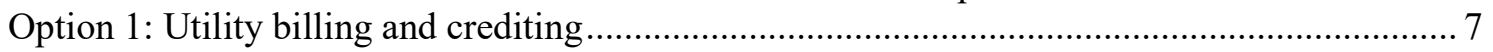

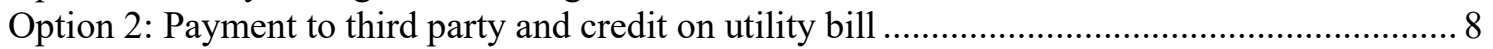

Option 3: Payment and crediting through building owner/aggregator of LMI subscribers .......... 8

3.3 Who is Responsible for LMI Customer Acquisition and Retention?......................................... 9

Option 1: The utility is responsible for LMI customer acquisition and retention...................... 9

Option 2: A third-party community solar developer responsible for LMI customer acquisition

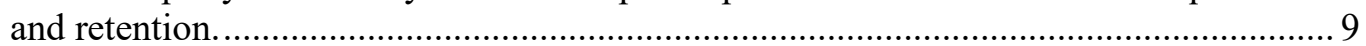

Option 3: Affordable housing facilities serve as subscribers on behalf of their tenants............. 10

3.4 How is Customer Eligibility Defined and Verified? ......................................................... 10

3.5 How Can Program Design Reduce Customer Turnover and Default Risk?............................ 11

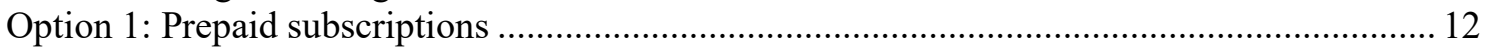

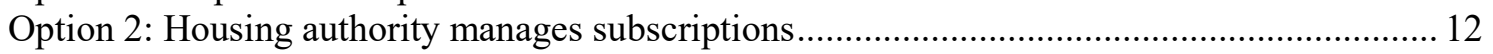

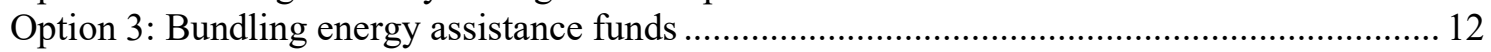

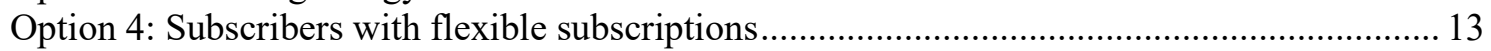

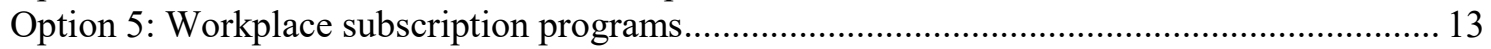

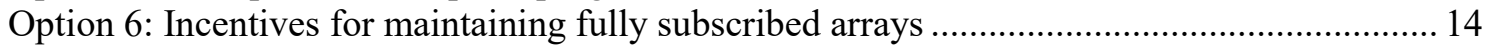

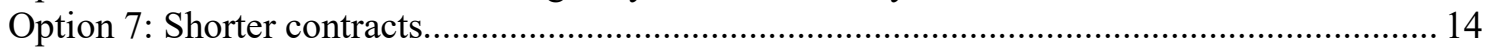

3.6 What are Strategies for Enrolling Customers with Low Credit Scores? .................................. 14

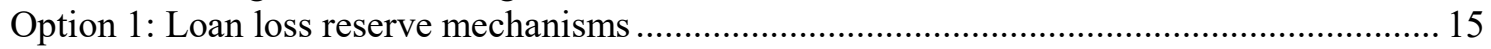

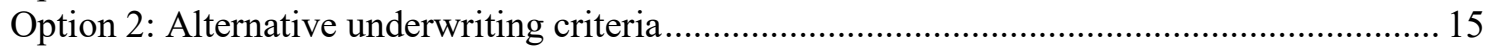

3.7 Where Should Community Solar Projects be Sited? ......................................................... 15

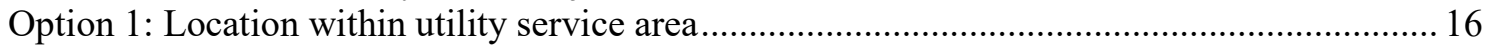

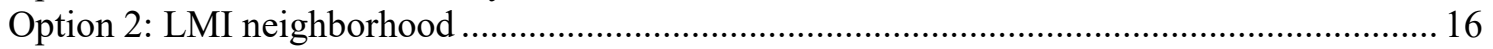

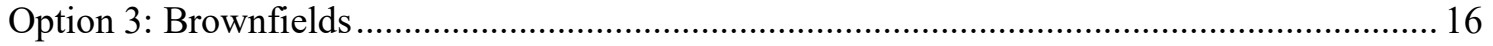

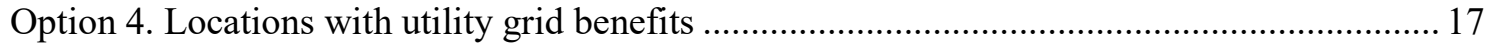

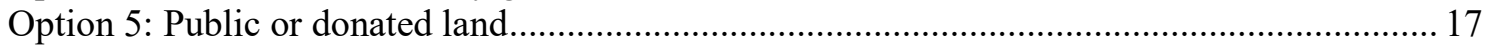

Option 6: Rooftop (e.g., affordable housing and mixed-income housing) ................................. 17

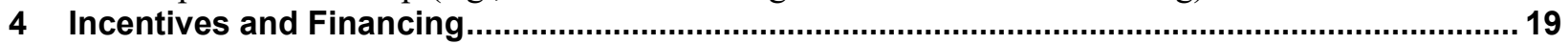

4.1 How Much Financial Incentive Do LMI Customers Need to Participate in Community Solar? 19

4.2 What Financing Strategies Exist to Help Cover Up-Front Cost? ............................................ 21

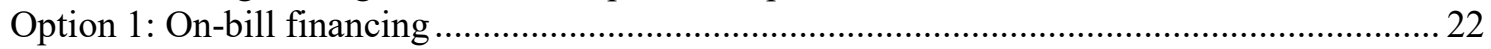

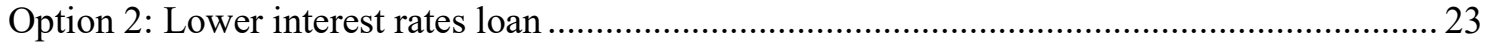

4.3 How Can Existing LMI Programs be Leveraged to Incentivize Community

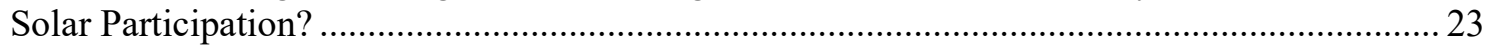

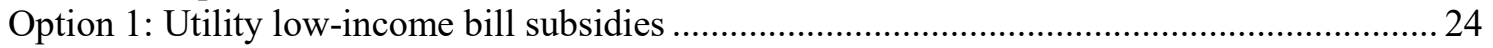

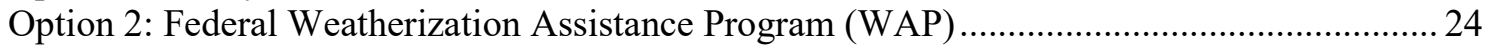

Option 3: Federal Low Income Home Energy Assistance Program (LIHEAP).......................... 25

4.4 What Other Incentives Help Developers Offer More Favorable Rates to LMI Customers?....... 26

Option 1: Community Reinvestment Act investments ............................................................. 26

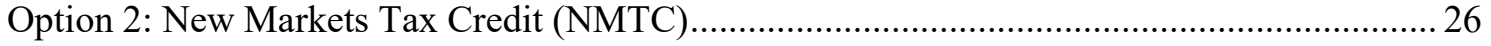




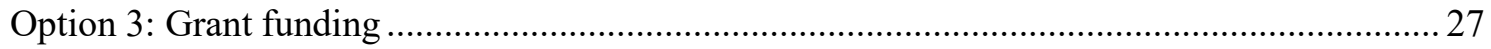

Option 4: Incentive multipliers or customer acquisition subsidies ......................................... 27

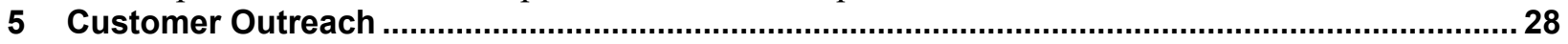

5.1 How to Reach Eligible LMI Customers and Potentially Target Specific Customer Types?....... 28

5.2 What Are Effective Partnerships for LMI Customer Outreach? .............................................. 29

5.3 What Are Effective Messaging Strategies to Reach LMI Customers? .................................... 31

5.4 What Are Effective Communications Vehicles? ................................................................... 32

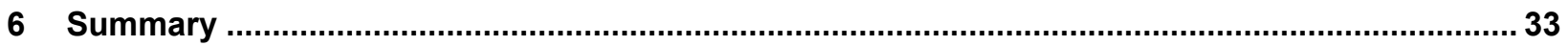

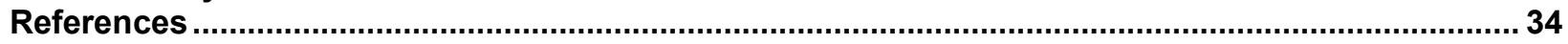

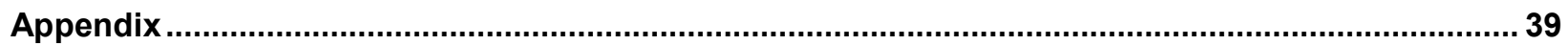

Overview of Existing Programs - Information Current as of May 2018 ......................................... 39

List of Community Solar Developers................................................................................................ 44

\section{List of Figures}

Figure 1. States with a community solar program with an LMI component .......................................... 2

Figure 2. Considerations for LMI participation in community solar ....................................................... 22

Figure 3. Trusted sources of information for community solar programs among low-income

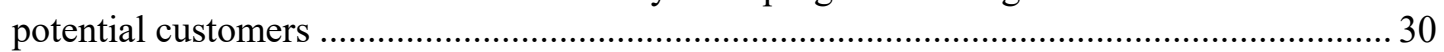

Figure 4. Most compelling messaging for LMI customers based on survey data.................................... 31

Figure 5. Most effective messaging channels for LMI community solar customers .............................. 32

\section{List of Tables}

Table 1. Summary of Existing LMI Community Solar Programs ........................................................... 3

Table 2. Washington, D.C. Solar for All Innovation and Expansion Grant Projects Funded

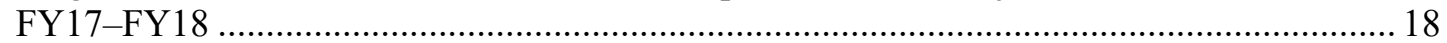

Table 3. Variations in Community Solar Pricing and Product Structures ............................................. 20

Table 4. Options for Using Community Solar to Reduce Electricity Burden ........................................... 21

Table 5. Hard-to-Reach Low-Income Customers ................................................................................. 28

Table 6. Partnerships for LMI Customer Outreach............................................................................... 30

\section{List of Text Boxes}

Text Box 1. Case Study: Colorado LMI Community Solar Programs ............................................... 6

Text Box 2. Washington, D.C.'s Solar for All Program ..................................................................... 18

Text Box 3. On-Bill Financing Options through Utility-Owned LMI Community Solar.................... 23 


\section{Introduction}

Community solar has emerged as a potential model to increase low- and moderate-income (LMI) solar access and reduce LMI energy burden (Gagne and Aznar 2018). In a community solar program, a utility or third-party owns a utility-scale PV array and sells portions of the array's power (kilowatts or $\mathrm{kW}$ ) or generation (kilowatt-hours or $\mathrm{kWh}$ ) to multiple subscribers. These subscribers pay voluntarily for their portion of the array and then receive a credit on their electricity bill for their share of production. This bill credit for generation produced may also include payment for the associated renewable energy certificates (RECs), depending on program structure. Subscribers can pay for their share through either an up-front payment or an ongoing monthly payment, such as through a financing option. SEPA (2015a) reported that $73 \%$ of active community solar programs in 2015 had an up-front payment, $17 \%$ had an ongoing payment, and $10 \%$ allowed subscribers to choose the option they preferred. Subscribers could also take out a private loan to pay an up-front payment.

Ensuring LMI participation in community solar can be challenging. As states and utilities seek to increase LMI community solar, they are looking for program and policy designs to facilitate LMI participation. Subscription models may need to be adjusted from the standard community solar offer. Programs may need to provide subsidies to LMI community solar subscribers to remove barriers related to up-front costs and to ensure the product provides immediate savings. Finally, those in charge of subscribing LMI community solar may need to find ways to work with LMI stakeholder groups to reach LMI customers.

This report draws from the literature and from interviews with representatives from LMI solar developers and state LMI community solar programs to provide experience on LMI community solar design. We interviewed stakeholders involved with LMI community solar in an informal manner, to gain insight into their key successes and barriers. The report is structured as follows. In Section 2, we review existing and emerging LMI community solar programs, with additional program detail provided in the appendix. In Section 3 we discuss key questions related to program design. Section 4 outlines how states can leverage incentives and finance structures to lower the cost of LMI community solar. Section 5 examines marketing and outreach considerations for LMI community solar. 


\section{Existing and Emerging State LMI Community Solar Programs}

States and utilities are rapidly adopting and developing LMI community solar policies and programs. Colorado, Connecticut, Hawaii, Maryland, and Oregon have all mandated community solar with a certain percentage (carve-out) of LMI customers; other states have provided incentives for LMI community solar (Colorado, Illinois, Massachusetts, Rhode Island, and Washington, D.C.); some states are in the process of developing programs (Connecticut, Minnesota, New York, New Jersey). Figure 1 and Table 1 summarize community solar programs with an LMI component. The appendix provides details on these programs. ${ }^{1}$

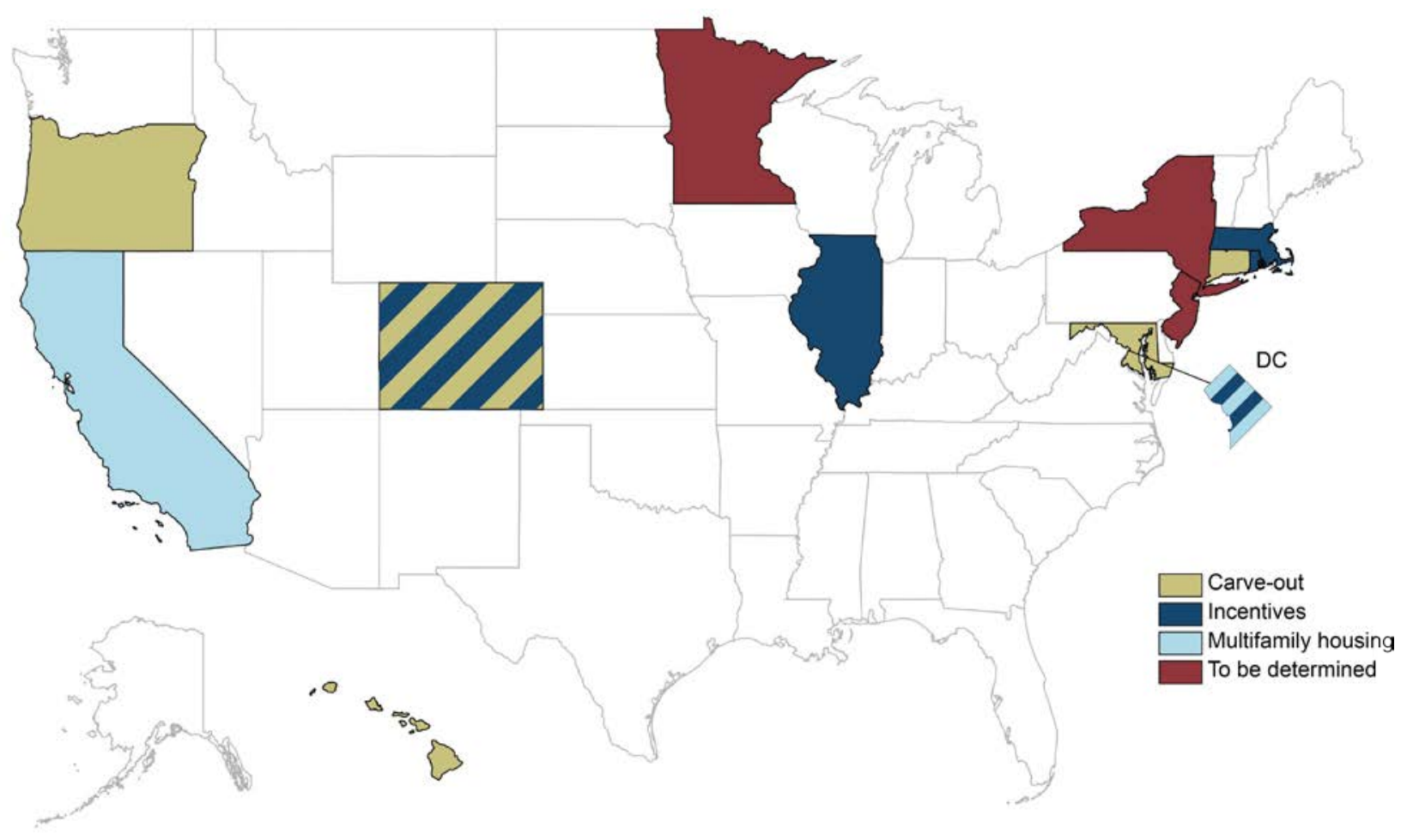

Figure 1. States with a community solar program with an LMI component

Information current as of May 2018

\footnotetext{
${ }^{1}$ See www.lowincomesolar.org for updates to low income community solar programs.
} 
Table 1. Summary of Existing LMI Community Solar Programs

Information current as of May 2018

\begin{tabular}{|c|c|c|}
\hline State Program & $\begin{array}{l}\text { Program Status } \\
\text { (Launch Date) }\end{array}$ & Program Structure \\
\hline $\begin{array}{l}\text { California Multifamily } \\
\text { Affordable Solar Housing }\end{array}$ & $\begin{array}{l}\text { Closed to new } \\
\text { applicants (2015) }\end{array}$ & $\begin{array}{l}\text { Incentives for solar systems on } \\
\text { multifamily housing }\end{array}$ \\
\hline $\begin{array}{l}\text { Colorado Community Solar } \\
\text { Gardens Act }\end{array}$ & Active (2011) & $\begin{array}{l}\text { Specified LMI participation levels: } 5 \% \text { of } \\
\text { each project designated through rulemaking }\end{array}$ \\
\hline $\begin{array}{l}\text { Colorado Low-Income } \\
\text { Community Shared Solar } \\
\text { Demonstration Projects }\end{array}$ & Closed (2015) & $\begin{array}{l}\text { Incentives for } 1.5 \mathrm{MW} \text { of dedicated LMI } \\
\text { community solar arrays }\end{array}$ \\
\hline $\begin{array}{l}\text { Colorado Xcel Energy } \\
\text { Settlement }\end{array}$ & Launched (2017) & $\begin{array}{l}13.5 \text { megawatts (MW) of RFPs for new LMI } \\
\text { community solar systems, Xcel Energy } \\
\text { assuming } 5 \% \text { carveout through new program } \\
\text { (under development) }\end{array}$ \\
\hline $\begin{array}{l}\text { Connecticut Shared Clean } \\
\text { Energy Facility Pilot Program }\end{array}$ & Active (2017) & $\begin{array}{l}5.2 \mathrm{MW} \text { across three projects, with } 20 \% \text { LMI } \\
\text { participation in each; Senate Bill } 9 \text { (2018) made } \\
\text { the Shared Clean Energy Facility program } \\
\text { permanent, allowing up to } 25 \mathrm{MW} \text { of projects per } \\
\text { year, with } 10 \% \text { of capacity towards low-income } \\
\text { subscribers, } 10 \% \text { to LMI or low-income service } \\
\text { organizations }\end{array}$ \\
\hline $\begin{array}{l}\text { District of Columbia Solar } \\
\text { for All }\end{array}$ & Active (2016) & $\begin{array}{l}\text { Program required to reduce electricity bills of at } \\
\text { least } 100,000 \text { low-income households by at least } \\
50 \% \text { (community solar is one piece of this } \\
\text { program); incentives for demonstration projects }\end{array}$ \\
\hline $\begin{array}{l}\text { Hawaii Community-Based } \\
\text { Renewable Energy }\end{array}$ & $\begin{array}{l}\text { In development } \\
(2015)\end{array}$ & $\begin{array}{l}\text { Specified LMI participation levels: } 50 \% \text { for } 9 \mathrm{MW} \\
\text { of utility-led projects }\end{array}$ \\
\hline $\begin{array}{l}\text { Illinois Community } \\
\text { Renewable Generation } \\
\text { Program }\end{array}$ & $\begin{array}{l}\text { In development } \\
(2016)\end{array}$ & $\begin{array}{l}\text { Incentives to LMI customers or developers: } \\
37.5 \% \text { of Solar for All funds will subsidize LMI } \\
\text { customer for community solar participation; } \\
22.5 \% \text { of funds will go to LMI community solar } \\
\text { pilot projects }\end{array}$ \\
\hline $\begin{array}{l}\text { Maryland Community Solar } \\
\text { Energy Generating Systems } \\
\text { Pilot Program }\end{array}$ & Pilot (2017) & $\begin{array}{l}\text { Specified LMI participation levels: } 60-M W \text { carve- } \\
\text { out for projects where LMI customers own } 20 \% \\
\text { of output; additional } 60-M W \text { carve-out for "small" } \\
\text { projects, including projects with more than } 50 \% \\
\text { LMI participation }\end{array}$ \\
\hline $\begin{array}{l}\text { Massachusetts Virtual Net } \\
\text { Metering }\end{array}$ & $\begin{array}{l}\text { Phasing out } \\
(2017)\end{array}$ & $\begin{array}{l}\text { Incentives to LMI customers: LMI customers are } \\
\text { eligible for low-interest financing from the Mass } \\
\text { Solar Loan program }\end{array}$ \\
\hline
\end{tabular}




\begin{tabular}{|l|l|l|}
\hline State Program & $\begin{array}{l}\text { Program Status } \\
\text { (Launch Date) }\end{array}$ & Program Structure \\
\hline $\begin{array}{l}\text { Solar Massachusetts } \\
\text { Renewable Target (SMART) }\end{array}$ & $\begin{array}{l}\text { In development } \\
(2017)\end{array}$ & $\begin{array}{l}\text { 1,600-MW declining block net-metering } \\
\text { program. Community solar serving at least 50\% } \\
\text { low-income customers receives an added 6 } \\
\text { cents/kWh; low income community solar projects } \\
\text { less than 25 kW will receive 230\% of the base } \\
\text { compensation rate }\end{array}$ \\
\hline $\begin{array}{l}\text { Minnesota Community Solar } \\
\text { Gardens }\end{array}$ & Active (2014) & $\begin{array}{l}\text { Utilities are required by commission to submit } \\
\text { plans for LMI projects. Xcel's pilot proposal } \\
\text { involves a 0.5-MW-1.0-MW system providing } \\
\text { free subscriptions to low-income customers }\end{array}$ \\
\hline $\begin{array}{l}\text { New Jersey Community Solar } \\
\text { Energy Pilot Program (Senate } \\
\text { Bill 877) }\end{array}$ & In development \\
$(2018)$ & $\begin{array}{l}\text { Senate Bill 877 directs the Board of Public } \\
\text { Utilities to develop a community solar pilot } \\
\text { program; the program must "provide access" to } \\
\text { LMI customers }\end{array}$ \\
\hline $\begin{array}{l}\text { NYSERDA Low Income } \\
\text { Community Solar Initiative }\end{array}$ & In development \\
(2017) & $\begin{array}{l}\text { NYSERDA is tasked with introducing an initiative } \\
\text { to provide financial support for pilot projects, } \\
\text { streamline pre-development assistance, and } \\
\text { develop LMI credit and support mechanisms } \\
\text { such as a loan loss reserve }\end{array}$ \\
\hline $\begin{array}{l}\text { Rhode Island Community } \\
\text { Oregon Community Solar }\end{array}$ & Active (2016) & $\begin{array}{l}\text { Specified LMI participation level of 10\%; rules } \\
\text { under development }\end{array}$ \\
\hline
\end{tabular}




\section{Program Design and Structure}

Different program structures have been used or are under consideration to promote LMI customer participation in community solar programs. In some cases, program design and structure are specified in legislation, however, in many cases, these details are developed as part of a public utilities commission stakeholder process. This section explores key aspects of program structure and implementation related to customer eligibility, subscription management, options for addressing low credit scores, bill crediting, and project siting. For each option addressed, we provide a table of advantages and disadvantages. These advantages and disadvantages pertain to that option and may be perceived differently among different stakeholders; where that is the case, we have noted that in the table.

\subsection{What is the Optimal Customer Participant Mix?}

The choice of customer mix involves tradeoffs around risk, financing cost, and ease of implementation. In general, projects with higher percentages of LMI customers are costlier to implement because of higher customer acquisition costs, the need for eligibility verification, and increased project financing costs. Developing a mix of LMI and non-LMI residential customers in the subscriber portfolio may reduce program costs; however, it may also increase complexity in terms of obtaining different types of subscribers. There are several possible approaches to developing the subscriber portfolio, discussed below. Some of these options could be implemented together, e.g. an LMI carve-out (Option 1) with a large anchor tenant (Option 3).

\section{Option 1: LMI carve-out}

The program can reserve a fraction of the project's capacity or generation for LMI customers and allow non-LMI customers to subscribe to the remaining share. For example, states have developed requirements for 5-20\% LMI participation, or higher. The non-LMI customers may bear some of the additional costs of the LMI customer portion, or the state may provide incentives to defray these additional costs. The carve-out could be implemented across a portfolio of community solar projects or apply to each project.

\section{Advantages \\ Disadvantages}

- Carve-outs ensure a minimum level of LMI participation.

- Non-LMI customers can also participate, which can keep costs lower for LMI customers.

- A wide range of customers are eligible (e.g., commercial).

- A broader mix of customers could reduce default risk.

- Maintaining LMI participation at a set level adds LMI customer acquisition costs to address turnover.

- Prescribing a minimum LMI requirement may serve as an artificial limit on LMI subscribers, as developers seek to only serve up to the minimum requirement.

- Non-LMI customers may bear some costs of LMI customer participation.

\section{Option 2: LMI-only project or program}

Community solar programs or projects can be designed and implemented exclusively for LMI customers. These projects have typically been deployed in a programmatic approach, for example, to reduce LMI energy burden. In this scenario, the array would be $100 \%$ subscribed by LMI customers. Text Box 1 describes the Colorado experience with carve-outs and dedicated LMI projects. 


\section{Advantages}

- It is easier to link to other LMI programs and offer specific incentives to LMI customers.

- Marketing materials can be designed exclusively toward LMI customers.

- It serves more LMI customer through a single community solar project.

\section{Disadvantages}

- Making the project financially viable for both the developer and the LMI participants can be more challenging, as LMI customers will have to support all project costs, instead of costs being spread among non-LMI and/or anchor tenants.

- Other customer classes may also want access to community solar.

- Third-party developers may see higher financial risk

\section{Text Box 1. Case Study: Colorado LMI Community Solar Programs}

The Colorado Community Solar Gardens Act (2010) established requirements for investor-owned utilities to offer community solar programs. The Act required the state's investor-owned utilities to propose ways to increase LMI subscriptions. The resulting public utility commission rulemaking set the requirement that investor-owned utilities reserve $5 \%$ of each community solar project's capacity for LMI customers. Project developers partnered with non-profits and public housing authorities to meet and maintain compliance with the LMI carve-out.

In 2015, the Colorado Energy Office commissioned a study of the LMI carve-out (Lotus Engineering and Sustainability 2015). Developers reported that the per-project carve-out was an inefficient way to increase LMI subscriptions, since project developers needed to invest resources to meet and maintain the carve-out for each project, instead of being able to manage the carve-out on a portfoliowide basis. Furthermore, because of the challenges associated with LMI customer acquisition, the study found that project developers met the LMI carve-out by giving away free subscriptions to LMI customers. Developers reported that higher project costs and lower project revenues meant higher prices for non-LMI customers.

To address the challenges of the $5 \%$ carve-out, stakeholders, including developers and advocates, suggested moving to a portfolio-based rather than project-based LMI target. A portfolio-based approach allows developers to increase LMI subscriptions by providing dedicated LMI community solar projects which offer incentives for low-income projects, including consideration of additional benefits to customers (bill savings, coordination with energy efficiency, job training opportunities). In 2016, the Colorado Public Utilities Commission approved the new portfolio-based LMI solar target. The policy requires Xcel Energy to provide LMI customers with access to $4 \mathrm{MW}$ per year of community solar capacity from 2017 to 2019 . The new program also provides incentives for an additional $0.5 \mathrm{MW}$ of projects annually dedicated exclusively to LMI customers.

Colorado's rural electric cooperatives (coops) and municipal utilities (munis) are exempt from the state's Solar Gardens Act. However, several coops and munis have implemented community solar programs with LMI components. In 2015, the Colorado Energy Office awarded a \$1.2 million grant to support coop and muni demonstration projects of LMI community solar (Colorado Energy Office 2017). Eligible projects were required to be dedicated exclusively to LMI customers and use different program structures to reduce energy burden for low-income customers. GRID Alternatives (the grantee) partnered with coops and munis to implement 8 demonstration pilot projects, totaling over $1.5 \mathrm{MW}$ of capacity, serving over 380 low-income customers. 


\section{Option 3: Anchor tenant}

Project developers can seek a single creditworthy non-residential anchor tenant to subscribe to a large portion of the project's capacity. For instance, the framework proposed by the Hawaii Public Utilities Commission allows a single anchor tenant to be any size up to $60 \%$ of a project's capacity.

\section{Advantages Disadvantages \\ - It can improve project economics and help developers obtain financing by reducing the risk associated with customer subscriptions. \\ - Allowing anchor tenants could reduce the number of LMI subscribers per array. \\ - Flexible anchor tenant agreements could mitigate customer turnover risk. \\ - Anchor tenants may be able to provide land or rooftop space for the community solar array. \\ Option 4: LMI participation incentives \\ Some states and programs are developing added incentives for LMI community solar subscribers. For example, if the state already has a solar renewable energy certificate (SREC) program, it may decide to award LMI community solar projects or subscribers a higher SREC rate. The incentive could be structured so that a community solar project would receive a higher SREC rate, for example, if half of the subscribers are LMI.}
Advantages
- Does not provide a cap (real or artificial) on LMI subscribers.
- Builds on existing incentive program structure.

\section{Disadvantages}

- LMI participation is not guaranteed.

- It may be difficult to set an incentive at an appropriate level; setting it too high would result in over-spending while setting it too low would result in low or no LMI participation.

\subsection{How are LMI Customers Billed and Credited for their Subscriptions?}

LMI customer billing and crediting arrangements depend in part on whether the customer has an individual meter or lives in a master-metered building. Another issue is whether payment for the community solar project is processed through the utility or made to a third party. The primary options are below.

\section{Option 1: Utility billing and crediting}

LMI community solar customer billing and crediting often occurs on the customer's existing utility bill. LMI customers in Colorado Energy Office demonstration projects, which are owned by utilities, contribute an on-bill payment and see a net utility bill line item deduction of around $\$ 0.04 / \mathrm{kWh}$ after accounting for payments and credits. Though the utility assumes the risk of nonrepayment, utilities are arguably in a good position to understand which customers are most likely to pay their electricity bills. This could enable utilities to subscribe LMI customers with no or poor credit ratings who have good bill payment history, as discussed in Section 3.5. 


\section{Advantages}

- This option is the simplest for subscribers, who pay a single bill.

- It may result in higher repayment by subscribers.

- It reduces risk for the project developer.

- Customers may be able to see the net benefit more clearly.

\section{Disadvantages}

- It may require utility billing software improvements.

- The utility assumes the risk of non-repayment, though non-repayments could be covered by existing LMI energy programs.

\section{Option 2: Payment to third party and credit on utility bill}

Alternatively, LMI customers can pay developers directly for their share of the community solar project through a separate billing mechanism, with the bill credit applied through the utility. In a program model in Connecticut, customers make monthly payments of $\$ 8$ directly to the developer and receive monthly bill credits of $\$ 10$ on their utility bill. Payments to developers can be facilitated via Automated Clearing House ( $\mathrm{ACH}$ ) transactions, so that customers do not need to write a check each month.

\section{Advantages}

- Utility doesn't assume risk of repayment for project developed by third-party.

- Third-parties can offer a discount for subscribers who pay using an Automated Clearing House $(\mathrm{ACH})$ transaction, since $\mathrm{ACH}$ transactions can reduce the risk of nonpayment.

\section{Disadvantages}

- Third-party assumes the risk of non-repayment, potentially increasing the cost of project finance.

- Subscribers would prefer only one bill.

- The risk of nonrepayment may be higher.

- The net benefit (bill savings) may not be as clear to subscribers.

\section{Option 3: Payment and crediting through building owner/aggregator of LMI subscribers}

LMI customers in master-metered buildings generally cannot be billed and credited directly for community solar subscriptions. In this context, the building owner, such as a multifamily affordable housing unit, may serve as the subscriber on behalf of its tenants. Direct bill crediting may be possible where the tenants have individual meters and where state policy allows. Under the California Multifamily Affordable Solar Housing program, customers are credited on their electricity bills through virtual net metering (EPA 2017). This structure requires that tenants pay their own electricity bills (i.e. the building is not master-metered). In Rhode Island, direct bill crediting is not required, but policy requires building owners to provide tenants with "tangible benefits" such as free Wi-Fi or improvements to common spaces.

\section{Advantages}

- It creates an on-bill credit, like Option 1.

\section{Disadvantages}

- The ability to share credits with tenants can be complicated in HUD housing, where customers pay a fixed $30 \%$ of income for rent and utilities.

- This option is restricted to states that allow this metering arrangement. 


\subsection{Who is Responsible for LMI Customer Acquisition and Retention?}

Depending on how programs are structured, utilities and third-parties may have different roles to play. Where utilities own the community solar arrays, they may play a larger role in customer acquisition and retention. Where community solar is owned by a third-party, the third party may have primary responsibility for subscription management. Another option is for an affordable housing authority or non-profit organization to assist.

\section{Option 1: The utility is responsible for LMI customer acquisition and retention.}

The advantage of this approach is that the utility can use its existing LMI energy program lists to generate leads for LMI community solar programs. It is possible that a utility could see a lower installed cost for the solar array, e.g. through their knowledge of best places for interconnection. Utilities can also work with affordable housing programs, existing LMI energy programs, and other LMI-focused groups to improve customer acquisition and retention.

\section{Advantages}

- Utilities may have access to lists of customers who already participate in energy assistance programs.

- Utilities can verify eligibility based on existing programs.

- Utilities are a known and potentially trusted entity.

- Utilities may be able to leverage other outreach efforts and programs to promote the solar option

\section{Disadvantages}

- If the utility does not own the array, it may not be incentivized to keep it subscribed.

- The utility may not have expertise marketing to LMI customers.

\section{Option 2: A third-party community solar developer responsible for LMI customer} acquisition and retention.

Under this approach, third-party community solar developers are responsible for meeting either a mandate or an incentive for LMI participation. ${ }^{2}$ For example, under Colorado's Community Solar Gardens Act, the Colorado Public Utilities Commission mandated that community solar developers subscribe each community solar array with 5\% LMI customers (Text Box 1).
Advantages
Disadvantages
- If the third party is receiving incentives for LMI subscribers, they will be motivated to ensure LMI participation.
- Third-party developers new to subscribing LMI customers may not have sufficient connections to LMI communities or organizations.
- Third party developers are often used to partnering on customer acquisition and have found ways to partner in the LMI space.
- Third-party developers may not have sufficient resources for sustained outreach and/or access to utility customer data on eligible customers.

\footnotetext{
${ }^{2}$ In some cases, other third-party organizations, such as community action agencies, may have lists of low-income eligible subscribers. In those cases, those agencies may be able to recruit subscribers at lower cost than organizations with no access to such lists.
} 


\section{Option 3: Affordable housing facilities serve as subscribers on behalf of their tenants.}

Under this approach, an affordable housing facility could host a community solar array and facilitate tenant subscriptions or pass-through of other benefits (e.g. building upgrades), if direct subscription were not an option (i.e., if the building were master-metered). The Denver Housing Authority is developing a community solar project and also acting as a subscriber, partnering with Grid Alternatives, Namaste Solar, and others, under Xcel's community solar program (SEIA 2018).
Advantages
Disadvantages
- Affordable housing facilities have direct access to LMI customers and may be able to easily enroll their tenants.
- Affordable housing facilities may be able to enroll new tenants as people move in and out of their facilities.
- Affordable housing facilities, especially small ones, may lack the staff capabilities to assist with subscription management.
- Master-metered buildings may make it impossible to pass subscription benefits directly to individual tenants.
- Affordable housing facilities can be trusted entities and known to their customers.
- Utility community solar programs and/or state net metering laws may prohibit this structure.
- Affordable housing, depending on its ownership structure, may be able to access low income housing tax credits for an on-site solar project.
- Tenants may not see any net savings, if their housing payment increases due to a decrease in utility expenses.

\subsection{How is Customer Eligibility Defined and Verified?}

Customer eligibility criteria can influence the ability to easily target customers and to verify their eligibility for participation in the program. Existing programs have used various methods for defining eligibility:

- Income qualified. Most programs use some type of income-based criterion. For example, the Maryland program defines LMI customers as those below $175 \%$ of the federal poverty line.

- Location qualified. For example, customers residing in environmental justice communities may be deemed program-eligible.

- Participation in an existing program. Another method is to make program eligibility consistent with pre-existing LMI energy programs, which can aid in the targeting and verification process. For example, several programs allow customers participating in state Low Income Home Energy Assistance Program (LIHEAP) programs to participate in LMI community solar programs, by default.

- Participation by LMI housing and service organizations. In some states, such as Colorado, Connecticut, Maryland, and Rhode Island, affordable housing operators can qualify as LMI participants.

Verification of eligibility is another important aspect of program implementation. One consideration is who will conduct the verification. Is it the utility, the developer, or a third party? Utilities may have data on customer income, bill payment history, and participation in bill 
assistance or other LMI programs. However, they may be unable to share this information because of data privacy concerns.

Third-party consultants can assist with verification while protecting the confidentiality of customer information, but the cost of using a third party would need to be covered under the program. The Massachusetts Clean Energy Center, which administers the Massachusetts Solar Loan Program, uses a third-party income verifier. Applicants fill out an online application. The income verifier uses this information to submit a request to the IRS for a tax transcript. Then, the income verifier compares the applicant's income against the program's income thresholds and provides an eligibility letter.

Perhaps the easiest method of verification is an option to link eligibility with other LMI programs, such as LIHEAP assistance, where participation can be readily verified. Under this and other verification structures, programs may want to consider the need for verification over time to ensure the program is meeting its LMI participation targets, if minimum thresholds exist.

Finally, the verification process will depend on the structure of the program. For example, for projects on LMI housing developments, the Massachusetts Department of Energy Resources verified the eligibility of the housing authority, not of the individual tenants; that piece was done by the housing authority. Housing developments had to have at least $25 \%$ of units serving $80 \%$ area median income (AMI) or 20\% of units serving 50\% AMI. For more information on customer eligibility criteria and income verification, see Clean Energy States Alliance (2017).

\subsection{How Can Program Design Reduce Customer Turnover and Default Risk?}

LMI customer retention is a significant issue for community solar projects, and the cost of acquiring new customers and replacing those that leave the program can be significant. One interviewee noted that LMI customer outreach is about subscription management, not just customer acquisition. ${ }^{3}$

Solar developers typically specialize in up-front customer acquisition but are unaccustomed to ongoing subscription management. For this reason, effective subscription management may require a partnership with a utility or community organization with an ongoing relationship with potential subscribers.

Furthermore, there can be significant turnover among LMI customers, particularly in renter populations. Customers need to be replaced when others move. Therefore, LMI customer acquisition is an ongoing process. Existing programs in Colorado have experienced high turnover among LMI customers, even where participation in the program comes at no cost to the subscriber. One community solar developer reported that a substantial number of customers ceased participation in the program after the first year, and that these customers were often

\footnotetext{
${ }^{3}$ Related to customer turnover is the issue of subscriber termination fees and process. From an LMI participant perspective, programs need to be designed with termination fees and processes that will not harm their credit rating. Programs that allow a subscriber to retain their subscription if they move within the utility service territory can reduce the need for LMI customers to terminate their subscription.
} 
renters. This has required the developer to maintain a long waiting list to be able to maintain the required level of LMI customer participation.

There are many ways to address customer turnover, depending on who is responsible for customer retention as well as how products are structured. Options to address customer turnover include the following seven options.

\section{Option 1: Prepaid subscriptions}

Prepaid subscriptions would use external funding for an up-front payment of the subscription. This funding could be provided via state funds, grants, or other options. ${ }^{4}$ In a prepaid subscription, the LMI subscribers, using external funding sources, would be subscribed for set time (e.g. 15 years) and receive credits on their electricity bills for that duration. If the entire LMI subscription could not be prepaid, policies could at a minimum allow for some mix of payas-you-go and prepaid subscriptions to diversify the subscriber base and improve the project risk profile (Chan, Ernst, and Newcomb 2016; Garren et al. 2016; SELC 2016).

\section{Advantages}

- It eliminates the possibility of customer default, as customers have no on-going payment.

\section{Disadvantages}

- It requires funding via state funds, grants, or other options.

- Paid subscriptions would need to be reassigned if the LMI customer moves out of the subscription territory.

- Developers may be slow to re-assign subscriptions.

\section{Option 2: Housing authority manages subscriptions}

If programs allow affordable housing units to subscribe and pass the benefits on to their LMI tenants, there is little risk of customer turnover or default, as the building landlord would be the subscriber, rather than individual tenants. The Public Housing Agency of the City of St. Paul, Minnesota, is working with developer Geronimo Energy to subscribe $100 \%$ of their electricity use at 10 high-rise facilities, and in so doing is expecting to save $\$ 130,000$ per year, or $\$ 3.25$ million over 25 years. Rhode Island and Connecticut also allow affordable housing units to subscribe to LMI community solar.
Advantages
Disadvantages
- It eliminates the possibility of customer default, as the housing authority would be the off-taker.
- There are fewer issues with customer turnover, as the housing authority would be able to reassign benefits to new tenants.
- There can be complexities in crediting customers with direct bill benefits, depending on the housing arrangement.
- The structure creates an administrative burden for housing authority staff.

\section{Option 3: Bundling energy assistance funds}

Reducing the price of an LMI community solar subscription can be done by lowering the LMI subscriber's electricity consumption. By using existing energy efficiency and conservation funds,

\footnotetext{
${ }^{4}$ For more on financing options, see Section 4.
} 
either from federal, state, or utility programs, LMI subscribers can reduce their community solar subscription size. Since their subscription costs would be reduced, this would increase the likelihood that LMI subscribers would continue to pay their electricity bills and community solar subscriptions. The Colorado Energy Office required LMI participants in its grant-funded community solar projects to have already had their homes weatherized or be on the waiting list for weatherization. The use of federal energy assistance funds to purchase community solar subscriptions is discussed in Section 4.3.

\section{Advantages \\ - It can result in lower bills for LMI customers compared to community solar alone.}

\section{Disadvantages}

- Some LMI residences may not qualify for free weatherization upgrades, if, for example, their house is newer construction.

- Some homes may be on a long waiting list to be weatherized, thus delaying community solar subscriptions.

\section{Option 4: Subscribers with flexible subscriptions}

A large anchor tenant, such as a municipal government, could have a flexible subscription that temporarily increases to absorb the loss of subscriptions from LMI customers who move or drop out of the program. Non-anchor tenants could also serve this function. Cooperative Energy Futures is building community solar gardens in Minnesota that follow this model. It has "backup subscribers" such as churches, mosques, and cities that agree to cover defaults by participants. That structure is allowing Cooperative Energy Futures to subscribe customers with lower credit scores (Jossi 2017).

\section{Advantages}

- It reduces risk for the developer.

- It can reduce project financing costs and reduce the cost of subscription management.

\section{Disadvantages}

- Some acquiring of new customers may still be required.

- Flexible subscriptions may be bound to a preset amount (e.g., the tenant would take $40 \%-$ $50 \%$ of the project offtake).

\section{Option 5: Workplace subscription programs}

Having customers obtain their subscription through their employer could potentially help address turnover as well as credit risk issues. If all or some of the employees are LMI, then the community solar project would enable LMI participation. For example, the Vermont Energy Investment Corporation worked with a spin-off company, Sun Shares, to subscribe its employees to fulfill a $200-\mathrm{kW}$ solar array. The program structure allows employees of all incomes to participate (VEIC 2017).

\section{Advantages}

- It reduces risk for the developer.

- Employers have a pool of potential subscribers to address turnover.

- The employer could also serve as a flexibletenant, as described in Option 4.

\section{Disadvantages}

- Some new customers may still need be acquired.

- The employer would assume the time and cost of managing subscriptions. 


\section{Option 6: Incentives for maintaining fully subscribed arrays}

Programs can provide a financial incentive to third-party-managed community solar by providing lower compensation rates for unsubscribed energy. This would incentivize the third party to maintain full subscription. Policies for compensation of unsubscribed capacity can also provide a limited backstop for customer defaults (CCSA 2017).

\section{Advantages}

- It does not cost the utility anything to incentivize full subscription.

\section{Option 7: Shorter contracts}

Creating short contract durations (e.g. 2-5 years) and easier options for exiting contracts may make initial subscription easier but could increase turnover risk and subscription management costs. IREC (2016) suggests that minimum contract duration requirements should depend on available financing and acceptable administration costs associated with customer turnover. One option to facilitate shorter contracts at lower cost would be to have an intermediary purchaser with a longer-term contract. This intermediary purchaser would enable allow the community solar project to be financed, then they could assign credits to low-income customers.

$\begin{array}{ll}\text { Advantages } & \text { Disadvantages } \\ \text { - Subscribers may be more likely to participate. } & \begin{array}{l}\text { - It is riskier for the project developer and } \\ \text { financer. } \\ \text { - It could increase turnover and subscription } \\ \text { management costs. }\end{array}\end{array}$

Many of these program and contracting options minimize the risk of customer default. There is little to no experience with customer defaults to date, perhaps in part because the programs have been structured to fully subsidize subscriptions or reduce electricity bill expenditures. Customer defaults could also be mitigated by a loan loss reserve, though this approach has not been used to our knowledge. If a public entity or other organization could provide a financial backstop in case of default, this would allow developers to obtain lower-cost financing.

\subsection{What are Strategies for Enrolling Customers with Low Credit Scores?}

Low credit scores in LMI communities can pose a challenge to customers who need access to financial capital to participate in community solar. LMI customers may face higher interest rates or may not meet the credit criteria to qualify for loans to defray up-front subscription costs. ${ }^{5}$ One approach to address this challenge is to design programs with pay-as-you-go subscriptions with no up-front costs. Other options exist where a pay-as-you-go design is not possible.

\footnotetext{
${ }^{5}$ While some research has shown that low-income homeowners have lower credit scores on average than higherincome homeowners, research has also identified significant populations of low-income homeowners with credit scores high enough to secure financing (Paulos 2017).
} 


\section{Option 1: Loan loss reserve mechanisms}

Programs can create accounts to cover losses if LMI customers are unable to pay back their loans. Loan loss reserve mechanisms allow LMI customers to obtain financing at lower interest rates despite low credit scores. For example, the Mass Solar Loan Program in Massachusetts established a loan loss reserve account for each participating lender in the program.

\section{Advantages}

- It provides a backstop for losses, should they occur.

- If no losses occur, the funds are not used.

\section{Disadvantages}

- It requires some entity (typically the state) to provide up-front funding for the loan loss reserve.

- May not be sufficient if defaults are common.

\section{Option 2: Alternative underwriting criteria}

LMI customers may be able to demonstrate creditworthiness in ways other than through their credit score. For example, programs may be able to use utility bill payment history to establish creditworthiness. The Solstice Initiative, with DOE Solar Energy Technologies Office funding, is gathering customer data on income, FICO score, and utility bill repayment history to test whether new qualifying metrics would expand access to community solar to additional households. Solstice is a community solar developer and will enroll customers and compare their actual payment histories (DOE 2018).

\section{Advantages}

- It is potentially a more accurate way of assessing likelihood of subscriber repayment.

- It could expand the number of possible subscribers.

\section{Disadvantages}

- The success of using alternative underwriting criteria for solar financing is being researched, but to date is largely unknown.

\subsection{Where Should Community Solar Projects be Sited?}

Deciding where to locate a community solar project can involve several considerations, including the land and interconnection costs that impact overall project costs, grid considerations for siting the project, as well as the visibility of the project and proximity to customers. To date, programs have taken various approaches to address siting issues for community solar projects; some of the considerations and options include the following six options. 


\section{Option 1: Location within utility service area}

Community solar projects may generally be sited anywhere within the same utility service area as the subscriber base; how close the project is to subscribers may or may not be specified in the program design. For existing rules on community solar location requirements, see Cook and Shah (2018a).

\section{Advantages \\ Disadvantages \\ - This option provides a larger area to site the project compared to siting within a neighborhood or on a brownfield. \\ - It could result in lower land acquisition costs compared to siting within a neighborhood or on a brownfield. \\ - If the project is sited away from an LMI community, it may be less visible to the community, resulting in lower subscription rates and/or higher costs to subscribe LMI customers. \\ - This option is restricted to states that allow this metering arrangement.}

\section{Option 2: LMI neighborhood}

Several states require that community solar projects be sited in LMI communities; these policies do not require that community solar serve LMI subscribers. Siting within LMI communities may increase a sense of ownership in local communities, improve the visibility of the project, or allow engagement of local communities through volunteer labor and/or job trainees.

\section{Advantages Disadvantages}

- This option could enable local economic benefits such as job training.

- It may have environmental benefits by reducing reliance on local gas-fired peaking plants located near LMI communities.
- Siting in LMI communities does not provide direct benefits to LMI customers on their electricity bills, if they are not subscribers.

- Trying to site projects in dense urban neighborhoods may be economically infeasible because of lack of land availability and/or highpriced land.

- Siting in LMI communities may have the unintended consequence of increasing local land prices and rents.

\section{Option 3: Brownfields}

Local siting may repurpose urban contaminated sites such as landfills, mine sites, and Superfund sites. Assistance may be available to aid in brownfield siting. For example, the U.S.

Environmental Protection Agency provides technical assistance for community solar projects located on contaminated sites regulated under federal and state cleanup programs.

\section{Advantages}

- This option repurposes land that does not have many other potential uses.

- It preserves existing greenfields.

- Land costs could be less than for a greenfield development.

\section{Disadvantages}

- Project permitting may take longer than it would for a greenfield.

- Project development costs may be higher than those for a greenfield. 


\section{Option 4. Locations with utility grid benefits}

Some jurisdictions may be interested in exploring how to site community solar projects to maximize grid benefits. Utilities may be able to help determine beneficial locations on the grid where projects could help avoid congestion or otherwise needed grid upgrades.

\section{Advantages Disadvantages \\ - The utility could recoup some of the savings in exchange for facilitating the project. \\ - Sites providing favorable grid benefits may not be favorable for other reasons (e.g., not enough space or high-cost land).}

\section{Option 5: Public or donated land}

LMI community solar projects could be sited on suitable public lands or donated land. For government sites, details about the terms of the land lease, permitting terms, and the duration of the agreement are important considerations for development of community solar projects. In some cases, access to public lands may have more restrictions and the process of leasing may be more onerous than for private land.

\section{Advantages}

- Land may be low or no-cost to the developer.

\section{Disadvantages}

- In some cases, government lease rates can be higher than those of private landowners.

- Government sites may be unable to be permitted quickly or they cannot be guaranteed for 20 years of use.

- May impose additional restrictions.

\section{Option 6: Rooftop (e.g., affordable housing and mixed-income housing)}

Another option is to site smaller projects on LMI rooftops. For example, this could be done on multiple affordable housing units or on mixed income housing developments. Washington, D.C. is funding rooftop installations that provide benefits to low-income residents, through its Solar for All program (Text Box 2). ${ }^{6}$

\section{Advantages}

- This option may be particularly attractive in urban areas that are land-constrained.

- No cost to lease or purchase land.

\section{Disadvantages}

- It may require supportive state or utility metering policies.

- Installation costs may be higher for rooftop systems.

\footnotetext{
6 “Solar for All," Washington, D.C. Department of Energy \& Environment, https://doee.dc.gov/solarforall.
} 


\section{Text Box 2. Washington, D.C.'s Solar for All Program}

Washington D.C.'s Renewable Portfolio Standard Expansion Amendment Act (2016) established the District of Columbia Solar for All program. It requires the D.C. Department of Energy and Environment (DOEE) to reduce the electric bills of at least 100,000 low-income households by at least $50 \%$ by 2032 . DOEE proposed community solar as one of several strategies to meet the Solar For All requirements. The program is funded through alternative compliance payment revenue. From 2017 to 2019 , DOEE will provide $\$ 20 \mathrm{M}-\$ 45 \mathrm{M}$ to support 30-60 MW of solar projects in the district. As a first step, DOEE will provide $\$ 13$ million for low-income projects: $\$ 8$ million for multifamily, commercial, institutional buildings, and non-residential spaces, and $\$ 5$ million for single-family homes, small businesses, and non-profits. The projects funded in FY17-FY18 are primarily solar installations at affordable housing or community buildings, with the bill credits going to low-income households (Table 2). Other examples include: siting solar on university buildings and giving the associated solar renewable energy certificate (SREC) revenue to low-income households. One project is installing solar on multifamily buildings, with the savings achieved going to building upgrades, amenities, and resident services. Projects such as that come in at a lower cost per low-income customer and per Watt; but in that case, customers are not receiving a tangible benefit such as free electricity.

Table 2. Washington, D.C. Solar for All Innovation and Expansion Grant Projects Funded FY17-FY18

\begin{tabular}{|c|c|c|c|c|c|c|c|}
\hline Grantee & Project Type & Benefit to Low-Income Customers & $\begin{array}{l}\text { Project Size } \\
\text { (kW) }\end{array}$ & $\begin{array}{l}\text { Total Grant } \\
\text { Amount }\end{array}$ & $\begin{array}{l}\text { Low-Income } \\
\text { Customers } \\
\text { Supported }\end{array}$ & Cost/Watt & $\begin{array}{l}\text { Cost/Low- } \\
\text { Income } \\
\text { Customer }\end{array}$ \\
\hline $\begin{array}{l}\text { Community } \\
\text { Preservation and } \\
\text { Development Corp. }\end{array}$ & $\begin{array}{l}\text { Installations on } \\
\text { multifamily buildings }\end{array}$ & $\begin{array}{l}\text { Building upgrades, new amenities, and resident } \\
\text { services }\end{array}$ & 1,000 & $\$ 300,000$ & 2,800 & $\$ 0.3$ & $\$ 107$ \\
\hline $\begin{array}{l}\text { Urban Energy } \\
\text { Advisors/NHT } \\
\text { Enterprise }\end{array}$ & $\begin{array}{l}\text { Installations on } \\
\text { affordable, } \\
\text { multifamily buildings }\end{array}$ & Not defined in the report & 1,000 & $\$ 1,517,655$ & 402 & $\$ 1.5$ & $\$ 3,775$ \\
\hline $\begin{array}{l}\text { Ethos Strategy } \\
\text { Consulting }\end{array}$ & $\begin{array}{l}\text { Installations at } \\
\text { affordable housing } \\
\text { properties }\end{array}$ & $\begin{array}{l}\text { "Direct payment" to low-income residents for } 25 \\
\text { years }\end{array}$ & 1,000 & $\$ 1,790,000$ & 350 & $\$ 1.8$ & $\$ 5,114$ \\
\hline $\begin{array}{l}\text { New Partners } \\
\text { Community Solar } \\
\text { Corp. }\end{array}$ & $\begin{array}{l}\text { Siting on community } \\
\text { buildings }\end{array}$ & $\begin{array}{l}\text { Free, } 25 \text {-year community solar subscriptions for } \\
\text { low-income households }\end{array}$ & 1,000 & $\$ 2,000,000$ & 325 & $\$ 2.0$ & $\$ 6,154$ \\
\hline Open Market ESCO & $\begin{array}{l}\text { Installations on } \\
\text { affordable, } \\
\text { multifamily buildings }\end{array}$ & $\begin{array}{l}\text { Free, } 15 \text {-year community solar subscriptions for } \\
\text { low-income households }\end{array}$ & 548 & $\$ 1,347,737$ & 195 & $\$ 2.5$ & $\$ 6,911$ \\
\hline $\begin{array}{l}\text { Community Power } \\
\text { Network - DC SUN }\end{array}$ & $\begin{array}{l}\text { Bulk procurement } \\
\text { for on-site solar on } \\
\text { low-income } \\
\text { households }\end{array}$ & Free on-site solar for low-income households & 750 & $\$ 2,000,000$ & 231 & $\$ 2.7$ & $\$ 8,658$ \\
\hline Groundswell & $\begin{array}{l}\text { Siting on community } \\
\text { buildings }\end{array}$ & $\begin{array}{l}\text { Free, } 20 \text {-year community solar subscriptions for } \\
\text { low-income households }\end{array}$ & 366 & $\$ 1,261,590$ & 122 & $\$ 3.4$ & $\$ 10,341$ \\
\hline $\begin{array}{l}\text { Neighborhood Solar } \\
\text { Equity, LLC }\end{array}$ & $\begin{array}{l}\text { Solar installations at } \\
\text { a local university }\end{array}$ & $\begin{array}{l}\text { SREC revenue to low-income households for } 15 \\
\text { years }\end{array}$ & 595 & $\$ 1,177,506$ & 100 & $\$ 2.0$ & $\$ 11,775$ \\
\hline $\begin{array}{l}\text { PEER Consultants, } \\
\text { P.C. }\end{array}$ & $\begin{array}{l}\text { Installations on } \\
\text { affordable, } \\
\text { multifamily buildings }\end{array}$ & $\begin{array}{l}\text { Free, } 15 \text {-year community solar subscriptions for } \\
\text { low-income households }\end{array}$ & 500 & $\$ 1,250,000$ & 100 & $\$ 2.5$ & $\$ 12,500$ \\
\hline
\end{tabular}




\section{Incentives and Financing}

LMI community solar projects generally have higher project financing, customer acquisition, and subscription management costs than projects where no LMI customers participate. In addition, LMI customers may need to receive a larger financial benefit from subscribing than non-LMI customers, in order to sign up. Some type of incentive may be necessary to defray these additional project costs and induce project developers to implement LMI community solar programs. In some cases, incentives go directly to developers, who can then pass along lower costs to LMI subscribers. In other cases, incentives may go directly to the LMI subscriber. In this section, we review how states can leverage incentives and financing structures to reduce the price of community solar for LMI customers.

\subsection{How Much Financial Incentive Do LMI Customers Need to Participate in Community Solar?}

Community solar pricing around the country varies considerably due to differences in available incentives, solar irradiance, electricity costs, and PV installation costs. In some markets, developers can offer products with no up-front payment and the ability to save from Day One. Payback periods vary depending on the up-front cost of the subscription, eligibility to take the federal investment tax credit, and the bill credits received. The production of the customer's share is typically credited at the retail rate and may include a REC or incentive payment. Table 3 provides a sample of community solar pricing and structures from around the country (for projects designed for all customer classes, not LMI specifically). While this list is not comprehensive, products were selected to provide a range of options currently available. While immediate savings are available through products offered in Massachusetts and Minnesota, all other products are structured as an up-front payment with simple paybacks ranging from 7 to 12 years.

Subscription models with an up-front payment and multi-year payback periods are likely less feasible for LMI customers. While up-front payments could be financed through a traditional bank loan, LMI customers may not qualify, or they may have to pay high interest rates for such loans. To address concerns about affordability of community solar for LMI customers, programs are being designed either as a free program or as one with a minimal ongoing payment paired with a bill credit. For example, the Colorado Energy Office targeted a 30\%-50\% reduction in LMI bills through its community solar pilot programs. The targets were developed with the purpose of lowering LMI energy burden to the state average.

Program designers can decide how much to subsidize LMI participation in community solar by examining energy burden, according to the following equation:

Electricity energy burden = annual electricity expenditures/annual household income 
Table 3. Variations in Community Solar Pricing and Product Structures

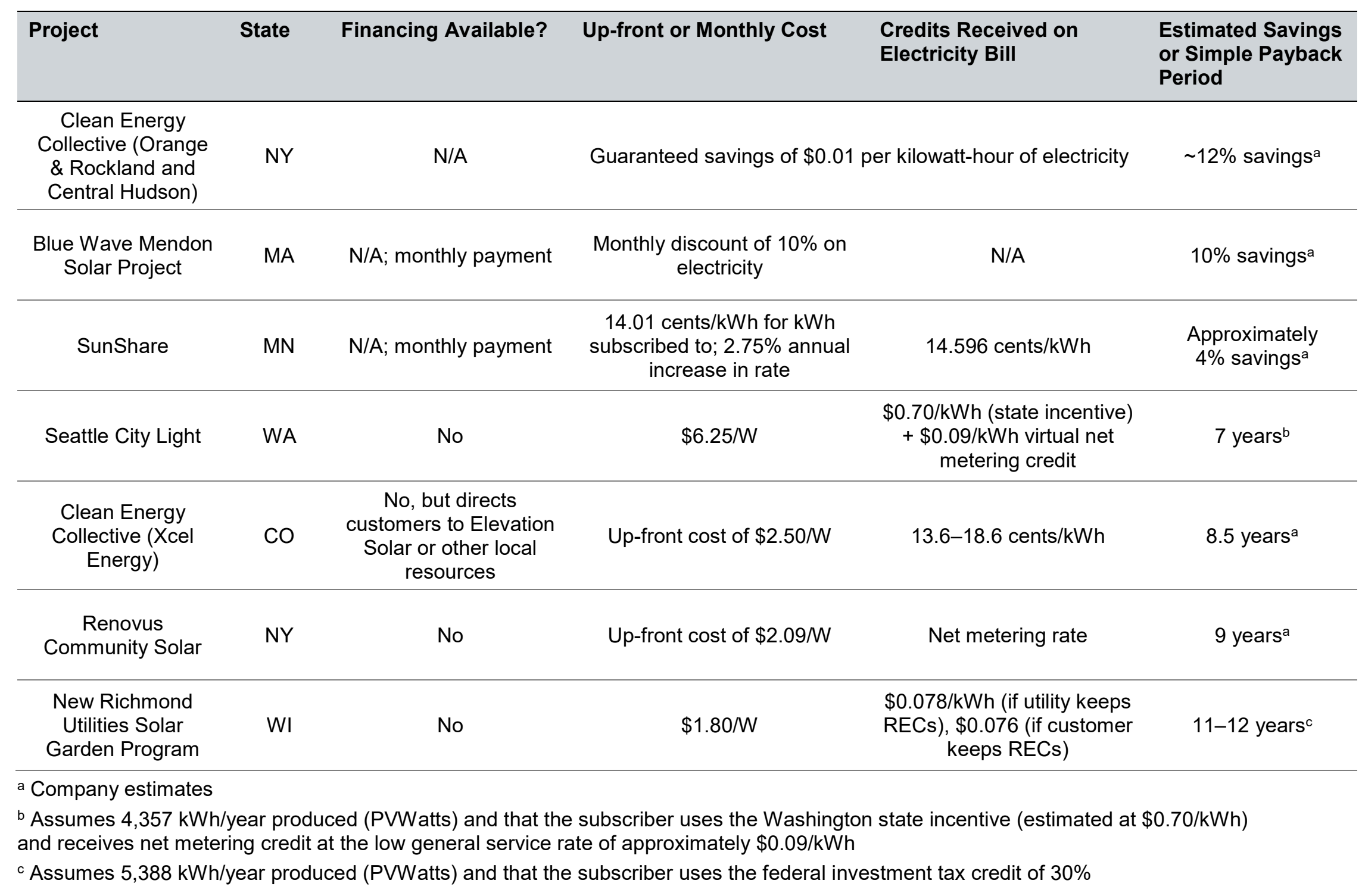


There are many ways a program could reduce electricity burden for LMI customers. Table 4 shows two examples using community solar: (1) provide free subscriptions (e.g., bill credits from the output of the subscription to the array) for part of a customer's electricity use or (2) provide reduced cost electricity from community solar for all of the customer's electricity use. These programs could be paired with weatherization efforts to minimize the bill savings required from the community solar subscription.

Table 4. Options for Using Community Solar to Reduce Electricity Burden

\begin{tabular}{lr}
\hline Assumptions & \\
\hline Annual electricity expenditures before solar & $\$ 1,000$ \\
Annual income & $\$ 25,000$ \\
Electricity burden before solar & $4 \%$ \\
Target electricity burden rate & $\$ 500$ \\
Reduction in annual electricity bill needed to meet electricity burden target & $\$ 0.12 / \mathrm{kWh}$ \\
All-in electricity rate & $8,333 \mathrm{kWh}$ \\
\hline Annual energy use & \\
\hline Example 1 & $4,167 \mathrm{kWh}$ \\
\hline Provide free electricity for $50 \%$ of customer's annual electricity expenditures & $3.2 \mathrm{~kW}$ \\
Solar size needed & $\$ 500.00$ \\
\hline Annual electricity expenditures after solar & \\
\hline Example 2 & $8,333 \mathrm{kWh}$ \\
\hline Provide reduced cost electricity for 100\% of customer's annual consumption & $\$ 500.00$ \\
\hline Solar size needed (kW) & \\
\hline Annual electricity expenditures after solar & \\
\hline
\end{tabular}

In both examples, the LMI customer is reducing annual electricity expenditures by one half, from $\$ 1,000$ to $\$ 500$. In Example 1, the LMI customer receives $\$ 500$ of free electricity, provided by a $3.2-\mathrm{kW}$ share of a community solar array, which provides $4,167 \mathrm{kWh}$ annually $(50 \%)$ of the customer's consumption. In Example 2, the LMI customer receives 100\% community solar at a price discounted from their exiting electricity rate $(\$ 0.06 / \mathrm{kWh}$ instead of $\$ 0.12 / \mathrm{kWh})$, from a $6.3-\mathrm{kW}$ share of a community solar array. These examples are for illustrative purposes only - to highlight different options for reducing LMI customer electricity bills through community solar.

\subsection{What Financing Strategies Exist to Help Cover Up-Front Cost?}

Up-front cost can be a significant barrier for LMI customer participation. In a survey of approximately 500 potential LMI community solar customers, the Pacific Consulting Group (2017) found the top three considerations for participating in community solar were up-front cost, percentage of bill covered, and initial contract duration (Figure 2). 


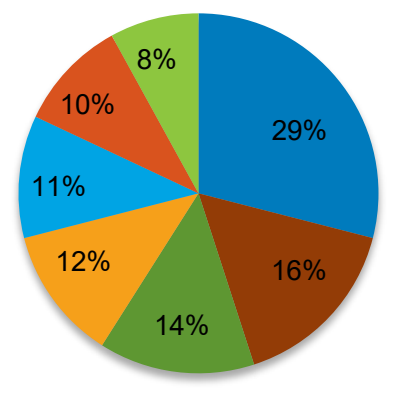

- Initial investment (29\%)

- Percent of bill covered (16\%)

n Duration of contract at initial sign-up (14\%)

- Incentive (12\%)

net monthly impact on bill 5 years out $(11 \%)$

- What you lease or own (10\%)

- Initial net monthly impact on bill (8\%)

Figure 2. Considerations for LMI participation in community solar

Source: Pacific Consulting Group (2017)

While some community solar programs are offered as part of a pay-as-you go model with zero up-front cost (e.g., the Blue Wave project in Massachusetts), most community solar programs require an up-front payment. ${ }^{7}$ Low credit scores pose challenges for LMI customers to obtain financing for solar products. Even for customers with strong credit scores, some LMI customers may be reluctant to take on a new line of credit to finance their solar investment, especially if financing requires a down payment. Several innovative financing schemes allow states to circumvent the challenges associated with traditional financing schemes:

\section{Option 1: On-bill financing}

On-bill financing allows customers to pay community solar subscription fees through ongoing payments on utility bills. On-bill financing may base creditworthiness on utility bill payment history rather than traditional credit criteria. For instance, the Grand Valley Power LMI program in Colorado allows LMI customers to pay subscription fees through on-bill financing. The program charges a subsidized subscription fee of $\$ 0.02 / \mathrm{kWh}$, which is simply subtracted from LMI customers' bill credits (see Text Box 2).

Utilities considering offering an on-bill financing option should consult with their regulators to ensure the service would be allowed. For example, in Texas, transmission and distribution utilities are not allowed to offer services that could be provided by competitive service providers unless they are mandated to do so by lawmakers. Regulators can be skeptical of on-bill financing, as the service may result in additional financial risk to the utility and/or costs being borne by non-participants (e.g., billing system upgrades) (RAP 2017).

\section{Advantages}

- LMI customers do not need to obtain up-front capital to fund their subscription.

- LMI customers would have both their payments and credits on their utility bill (can see net savings).

- The potential subscriber pool can be increased by using bill repayment history as a proxy for creditworthiness.

\section{Disadvantages}

- The risk of subscriber default falls on the utility.

- If the subscription is higher-cost than the default electricity product, subscribers are at higher risk for not paying their bill and being disconnected; disconnection would not happen if the loan were provided by a third party (RAP 2017).

- Utility financing may be restricted by regulators.

\footnotetext{
${ }^{7}$ The Blue Wave project is likely able to offer a zero up-front cost model because of the high SREC values in Massachusetts.
} 
Text Box 3. On-Bill Financing Options through Utility-Owned LMI Community Solar

\section{Grand Valley Power}

The Grand Valley Power (GVP) Solar Garden is a 100-kW utility-owned community solar array in Grand Junction, Colorado. GRID Alternatives operates and manages the array on GVP property. GVP manages subscriptions. The project serves eight LMI households in GVP's service territory. Housing Resources of Western Colorado, a non-profit energy efficiency services firm, vets eligible program participants. Subscribers receive monthly net metering credits at about $\$ 50 /$ month. Subscribers pay no up-front cost but pay a fee of about $\$ 0.02 / \mathrm{kWh}$, or about $\$ 9 / \mathrm{month}$, to defray management costs.

GVP also offers an on-bill financing program for a separate $17-\mathrm{kW}$ community solar array. The program allows customers to subscribe with no money down and a zero-interest loan paid through monthly on-bill installments of $\$ 15 /$ month for five years. The on-bill financing program is available to all GVP customers, regardless of credit history.

\section{Fort Collins Utilities}

The Fort Collins Utilities (FCU) Rooftop Solar Garden is a 65-kW utility-owned community solar array in Fort Collins, Colorado. The array serves about 20 LMI households per year in the FCU service territory and is qualified annually through the utility's Low-Income Energy Assistance Program, prioritizing customers who are all-electric. Subscribers receive a monthly bill credit worth about $\$ 25 /$ month that is designed to reduce subscriber energy burdens to $4 \%$ of annual income. Subscribers make no up-front or ongoing payments. Subscribers agree to complete FCU-provided energy efficiency upgrades and participate in energy education events.

\section{Option 2: Lower interest rates loan}

In Massachusetts, LMI customers are eligible for lower interest rates under the Massachusetts Solar Loan program. This can be used for community solar subscriptions in Massachusetts that require an up-front payment. The Mass Solar Loan program offers to reduce interest rates for solar loans by 1.5 percentage points. Furthermore, the program pays down $20 \%$ of the loan principal for customers below $120 \%$ of state median income, and $30 \%$ of the principal for customers below $80 \%$ of state median income.

\section{Advantages}

- LMI customers pay lower interest rates, thus making subscription more financially attractive.

\section{Disadvantages}

- Such loans require a subsidy to cover risk and buydown.

- Customers may be resistant to signing a loan.

Administrative process and paperwork could be barrier.

\subsection{How Can Existing LMI Programs be Leveraged to Incentivize Community Solar Participation?}

Existing rate subsidies for LMI households may support participation in community solar arrays. Programs could be designed to leverage utility low-income bill subsidies, federal LIHEAP dollars, and/or federal Weatherization Assistance Program dollars. 


\section{Option 1: Utility low-income bill subsidies}

Many utilities provide energy subsidies to low-income customers through ratepayer surcharges. These public utilities commission-mandated actions are known as utility-funded energy subsidies and are different from government assistance programs. Just as these "discounts" are given to lowincome citizens, they could also be used for community solar subscriptions. These dollars are separate from any government assistance programs described below. An informal survey by SEPA (2017a) found that nationally several utilities had bill reduction programs ranging from $10 \%$ to $50 \%$ of customers' bill. In California, the Interstate Renewable Energy Council (IREC 2016) has proposed using some of the revenue that supports the California Alternate Rates for Energy program to fund a 5-MW community solar pilot program.

\section{Advantages}

- This option would invest in an asset with potential financial return, instead of spending additional dollars each year.

\section{Disadvantages}

- It requires approval from state utility regulators.

- Would require buy-in from stakeholders involved, who may be reluctant to divert energy subsidies to solar investments.

\section{Option 2: Federal Weatherization Assistance Program (WAP)}

Federal appropriations provide formula grants to states to weatherize homes for low-income residents. Each state develops a plan outlining their weatherization goals, which are to be implemented by weatherization subgrantees. Those state plans are submitted to and approved by a DOE project officer. Though renewable energy has been approved for use under the Energy Policy Act of 2005, any project must be able to achieve a savings-to-investment ratio of 1.0 or greater. In addition to meeting the savings-to-investment ratio requirement, the maximum amount that could be spent on a renewable energy system was \$3,598 in 2017 (DOE 2017); this limits the size of system that could be installed. At $\$ 2.50 / \mathrm{W}$, the spending cap would limit installations to a $1.4-\mathrm{kW}$ system.

To date, no state has used WAP funds for community solar, though a recent WAP memo (DOE 2017) indicates this may be possible. New York is investigating this issue and has put it into their WAP state plan. WAP Memorandum $024^{8}$ outlines the general process for including solar and provides tools and resources for determining the savings-to-investment ratio.

\footnotetext{
8 "WAP Memorandum 024: The Use of Solar PV in the WAP," DOE, https:/www.energy.gov/eere/wipo/downloads/wap-memorandum-024-use-solar-pv-wap.
} 


\section{Advantages}

- This option would invest in an asset with potential financial return, instead of spending additional dollars each year.

\section{Disadvantages}

- Getting a state plan approved and implemented could be time-consuming.

- Individual project approval could be timeconsuming.

- No examples exist to our knowledge of a WAP being used for community solar.

- The funding amount is capped so that the system purchase may not meet $100 \%$ of the household's electricity needs (depending on the household size) unless paired with other funding mechanisms.

\section{Option 3: Federal Low Income Home Energy Assistance Program (LIHEAP)}

Federal LIHEAP dollars are used to provide energy bill assistance to low-income residents. The program primarily provides bill assistance by paying the utility. LIHEAP dollars are also used for weatherization efforts (typically $5 \%-15 \%$ of a state's LIHEAP allocation go to weatherization). If a low-income resident were a subscriber to a community solar array, LIHEAP dollars could be used to pay their community solar subscription, though this structure has not been used to our knowledge. A few states are exploring using funds they typically allocate from LIHEAP to pay for multifamily solar or community solar projects.

While no state has used LIHEAP or WAP funds for community solar, Colorado is using a combination of WAP and LIHEAP dollars, along with funding from the state's two investorowned utilities, to install solar on 300 single-family homes This was the first solar PV pilot supported by the WAP, and it installs panels on homes that will also have energy efficiency upgrades. New York was more recently approved by their federal project officer to use WAP dollars for solar on multifamily buildings. ${ }^{9}$

\section{Advantages}

- This option would invest in an asset with potential financial return, instead of spending additional dollars each year.

- This option could result in more households reached with federal dollars, since fewer households would need ongoing energy assistance if their community solar subscription were pre-paid via federal funds.

\section{Disadvantages}

- Getting a state plan approved and implemented could be time-consuming.

- No examples exist to our knowledge of LIHEAP being used for community solar.

\footnotetext{
${ }^{9}$ To get approval, New York included solar for multifamily buildings in its state WAP plan, which then was approved by its federal project officer.
} 


\subsection{What Other Incentives Help Developers Offer More Favorable Rates to LMI Customers?}

Unlike some other customers, LMI customers may require quicker returns (e.g. savings from day-one) from community solar participation. Incentives may be necessary to help developers offer more favorable rates to LMI customers without overburdening other subscribers. Examples of incentives include the following four options.

\section{Option 1: Community Reinvestment Act investments}

Some banks may be willing to invest in community solar and donate the shares to LMI customers, thus eliminating the up-front cost barrier, as one way to fulfill their Community Reinvestment Act (CRA) obligations. Alpine Bank purchased $25 \mathrm{~kW}$ from Clean Energy Collective's Breckenridge Ullr Community Solar Array in Colorado. The bank then donated the shares to the Family \& Intercultural Resource Center, which assigns monthly bill credits to local families needing assistance. This structure enables Clean Energy Collective to meet the 5\% LMI carve-out requirement. Alpine Bank benefits from being able to take a tax deduction for the donation as well as potentially being able to use the donation to meet CRA obligations. Federal regulators recently clarified that investments in off-site renewables are eligible for banks to use to demonstrate CRA activities, "so long as the benefit from the energy generated is provided to an affordable housing project or a community facility that has a community development purpose" (Federal Register 2016).

\footnotetext{
Advantages

- CRA investments would reduce the cost of LMI subscriptions.

- Banks could bundle CRA investments with their own subscription to gain a bulk discount (as Alpine Bank did).

- Can be financially beneficial for a bank.
}

\section{Option 2: New Markets Tax Credit (NMTC)}

Project developers could also use the New Markets Tax Credit (NMTC) to lower the cost of community solar subscriptions. The NMTC provides investors with a tax credit of $39 \%$ of the qualified equity investment made, realized over a seven-year period. The NMTC applies to investments made in business or economic development projects located in census tracts where the poverty rate is at least $20 \%$ or where median family income does not exceed $80 \%$ of the area median. The NMTC has been used for utility-scale solar arrays (e.g., 1.65 MW in Salt Lake County and 1.56 MW in Cincinnati) (NDC 2015), but no examples of NMTC being used for community solar exist to our knowledge. One project in California used NMTC to finance solar on affordable multifamily housing units, taking advantage of California's Multifamily Affordable Solar Housing virtual net metering program as well. The project provided solar energy to tenants at no cost (Treasury 2011). 
Advantages

- NMTC would lower the project cost and enable greater LMI participation.

\section{Disadvantages}

- Obtaining NMTC can be a complex process.

- No NMTC examples for community solar exist.

\section{Option 3: Grant funding}

Several states are providing — or plan to provide — grant funding for LMI community solar projects. Some states have conditioned funding on requirements that the demonstration projects benefit LMI customers. Grant funding can be also tailored to provide additional benefits, such as job training. For example, the Colorado Energy Office provided $\$ 1.2$ million in grant funding for 8 LMI demonstration projects. The grant funding was used to achieve a $50 \%$ target energy burden reduction for LMI customers. The Connecticut pilot program favors project proposals with more than $20 \%$ LMI participation. Washington, D.C. provided up to $\$ 100,000$ for projects that demonstrate how community solar can benefit LMI customers.

\section{Advantages \\ - This option would directly lower the project cost and enable greater LMI participation. \\ - Grant-making organizations may be able to fulfill multiple objectives (e.g., including job training).}

\section{Disadvantages}

- It requires state or other appropriations.

- It may not be sustainable for future projects.

\section{Option 4: Incentive multipliers or customer acquisition subsidies}

Many states have existing solar incentive programs, such as net metering, solar renewable energy certificate (SREC), and low-interest loan programs. LMI customer participation in community solar programs can be subsidized through incentive multipliers in such pre-existing programs. For example, the Mississippi net metering program included a $\$ 0.02 / \mathrm{kWh}$ net metering adder for the first 1,000 income-qualified LMI customers to enroll in the program. State programs could also provide per-customer subsidies to defray the costs of LMI customer outreach (see Section 5). For instance, the Rhode Island program provides a $\$ 200$ subsidy to developers for each LMI customer subscription. The program requires developers to pass the subsidy through to the customer in the customer's rate agreement.

\section{Advantages \\ - It provides flexibility for developers to enroll as many LMI customers as possible.}

\section{Disadvantages}

- Setting an appropriate incentive amount may be challenging.

- It requires state or other appropriations.

- May still have risk of under-enrollment. 


\section{Customer Outreach}

Interviewees consistently cited customer outreach as a primary challenge of implementing LMI community solar programs. The first outreach challenge is to identify program-eligible LMI customers. The second challenge is to enroll program-eligible customers through effective messaging catered to LMI customers. Ongoing partnerships may be a crucial component of effective customer outreach. Challenges with reaching LMI customers can increase customer acquisition and retention costs.

\subsection{How to Reach Eligible LMI Customers and Potentially Target Specific Customer Types?}

In general, one of the biggest challenges with obtaining participants in community solar projects is getting the attention of customers and having the opportunity to explain the program. For subscriber-based programs like community solar, gaining access to customers is a key challenge, and it can be more pronounced for LMI customers, who can be even more difficult to reach.

Lessons from energy efficiency programs that target LMI customers indicate several LMI customer types are particularly difficult to reach, including renters, foreign language-speaking households, and others (Table 5). For these reasons, piggy-backing on existing LMI programs or partnering with groups that are regularly interacting with the LMI community can be effective. Some programs have relied on referrals of existing participants to spread the word. Often, this can be effective once a customer experiences real financial benefit from a program. Referrals from friends and relatives can provide a trusted source of information for LMI customers who may be leery of third-party marketing efforts. Referrals have been shown to be a successful way of acquiring residential PV customers, providing $\$ 250$ to over $\$ 1,000$ in rewards to an existing customer for their successful referral (GTM 2017). GTM (2017) estimates the cost of referrals at $\$ 0.31 /$ Watt with community events also being a lower-cost customer acquisition option, at $\$ 0.40 /$ Watt. These estimates are for on-site residential PV systems.

Table 5. Hard-to-Reach Low-Income Customers

Hard-to-Reach Low-Income Customers

Renters in multifamily properties

Rural households

Foreign-language-only households

Undocumented immigrants

Seniors

People with disabilities

Source: Hoffman 2017

Program eligibility definitions can also exacerbate customer outreach challenges if eligibility requirements are complex, require income documentation from customers, or are otherwise difficult to verify. Easily verified eligibility criteria facilitate the identification of programeligible customers, while complex criteria or criteria that are difficult to readily verify can make 
it more challenging to target customers and conduct outreach through partners. For example, customers may not be willing to provide certain types of documentation of their income levels.

A common method to facilitate LMI customer identification is to define program eligibility consistently with pre-existing programs. For example, several programs allow customers participating in state LIHEAP programs to participate in LMI community solar programs, by default. Consistent program eligibility criteria across LMI programs allow outreach coordinators to use existing lists of program-eligible LMI customers. One outreach coordinator noted that customers who already participate in other LMI energy programs are more likely to enroll in LMI community solar programs.

\subsection{What Are Effective Partnerships for LMI Customer Outreach?}

Several interviewees reported that effective LMI customer outreach requires engagement with multiple partners. Effective partnerships may reduce program costs associated with LMI customer identification and acquisition. Partners can include a variety of types of organizations (see Table 6) such as utilities, community LMI groups/NGOs, low-income weatherization or efficiency programs, housing authorities, or solar developers. Each of these can play a slightly different role in the program - from basic education and outreach to potentially enrolling customers directly. In some cases, affordable housing programs can play a role in subscription management as well.

The most promising partners are generally those that are trusted and have frequent touch-points with LMI customers to leverage existing outreach efforts and channels. It can be effective to approach LMI customers with a bundle of several related programs and use existing outreach for related offerings, such as efficiency programs. These partners often are known within the LMI community and can have the trust of community members, which is important for subscribing customers. Figure 3 presents survey data from potential low-income customers, ranking their preferences for sources of information on community solar programs, from most trusted sources (10) to least trusted sources (0). 
Table 6. Partnerships for LMI Customer Outreach

\begin{tabular}{ll}
\hline Partner & Value of the Partnership \\
\hline Utilities & $\begin{array}{l}\text { Utilities have the most direct access to customer information and can } \\
\text { most readily estimate customer energy burdens and customers } \\
\text { participating in low-income programs. Some utilities already have rate- } \\
\text { subsidized customers that may automatically be eligible for LMI } \\
\text { community solar programs. Also, utilities are known by LMI customers } \\
\text { with outreach channels. }\end{array}$ \\
\hline $\begin{array}{l}\text { Community LMI } \\
\text { groups/NGOs }\end{array}$ & $\begin{array}{l}\text { While utilities may be trusted sources of information (Figure 3), LMI } \\
\text { customers may still be skeptical of their utility. Working with a non-utility } \\
\text { partner may help programs overcome LMI customer skepticism. } \\
\text { Community groups already have established relationships with LMI } \\
\text { customers that facilitate customer education and acquisition. }\end{array}$ \\
\hline $\begin{array}{l}\text { Existing LMI programs } \\
\text { (e.g., LIHEAP) }\end{array}$ & $\begin{array}{l}\text { Collaboration with other LMI programs to raise awareness can be } \\
\text { effective. Leveraging existing outreach materials can reduce subscription } \\
\text { costs. }\end{array}$ \\
\hline Housing authorities & $\begin{array}{l}\text { Housing authorities have access to customers for outreach. They may be } \\
\text { able to serve as the community solar subscriber and pass benefits } \\
\text { through to their tenants. }\end{array}$
\end{tabular}

Solar developers

Solar developers can provide expertise on customer acquisition, even if these practices must be modified in the LMI context.

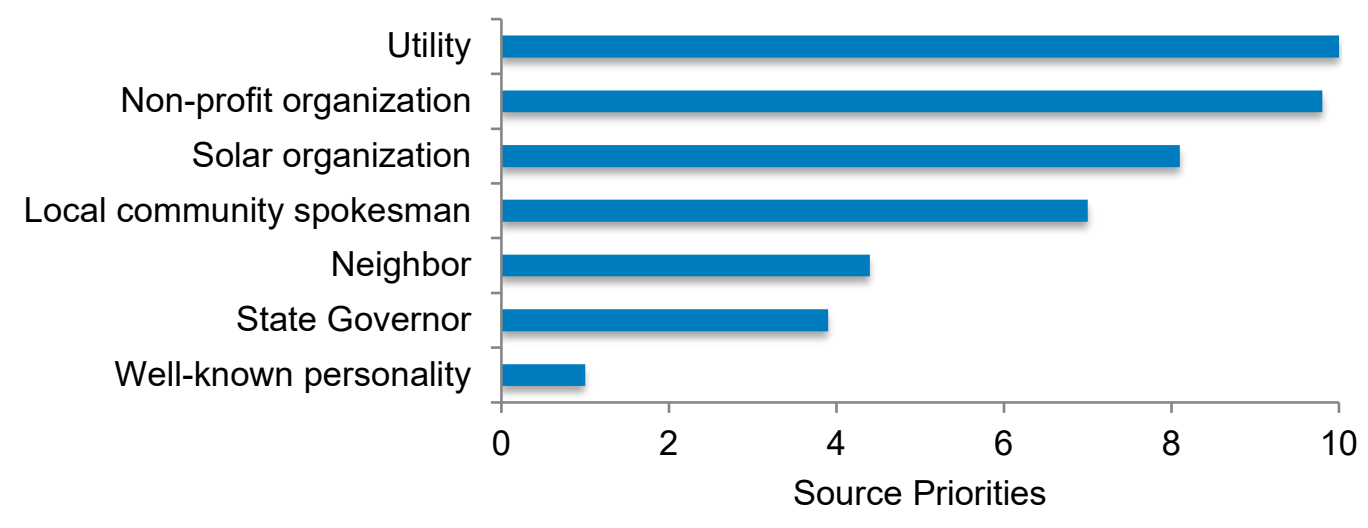

Figure 3. Trusted sources of information for community solar programs among low-income potential customers

Source: Pacific Consulting Group 2017 


\subsection{What Are Effective Messaging Strategies to Reach LMI Customers?}

Several interviewees stated that LMI customer outreach requires different messaging techniques than typical solar customer acquisition. However, if community solar projects can offer customer savings from the outset (e.g., through pay-as-you-go models that yield net savings), overall customer messaging strategies about savings may be the most effective for all customer types. However, for community solar projects in markets where the economics are not attractive for all customers, such messaging may not be feasible.

In addition to cost savings, ease of access can be important. A survey of approximately 500 potential LMI customers that was conducted by Pacific Consulting Group (PCG 2017) found that the most appealing messaging to respondents was messaging about availability to everyone (homeowners and renters), no start-up costs, cost savings, and the ability to buy solar immediately (see Figure 4). Messages about the environmental benefits and the fact that community solar is local were among the next most appealing messages (PCG 2017).

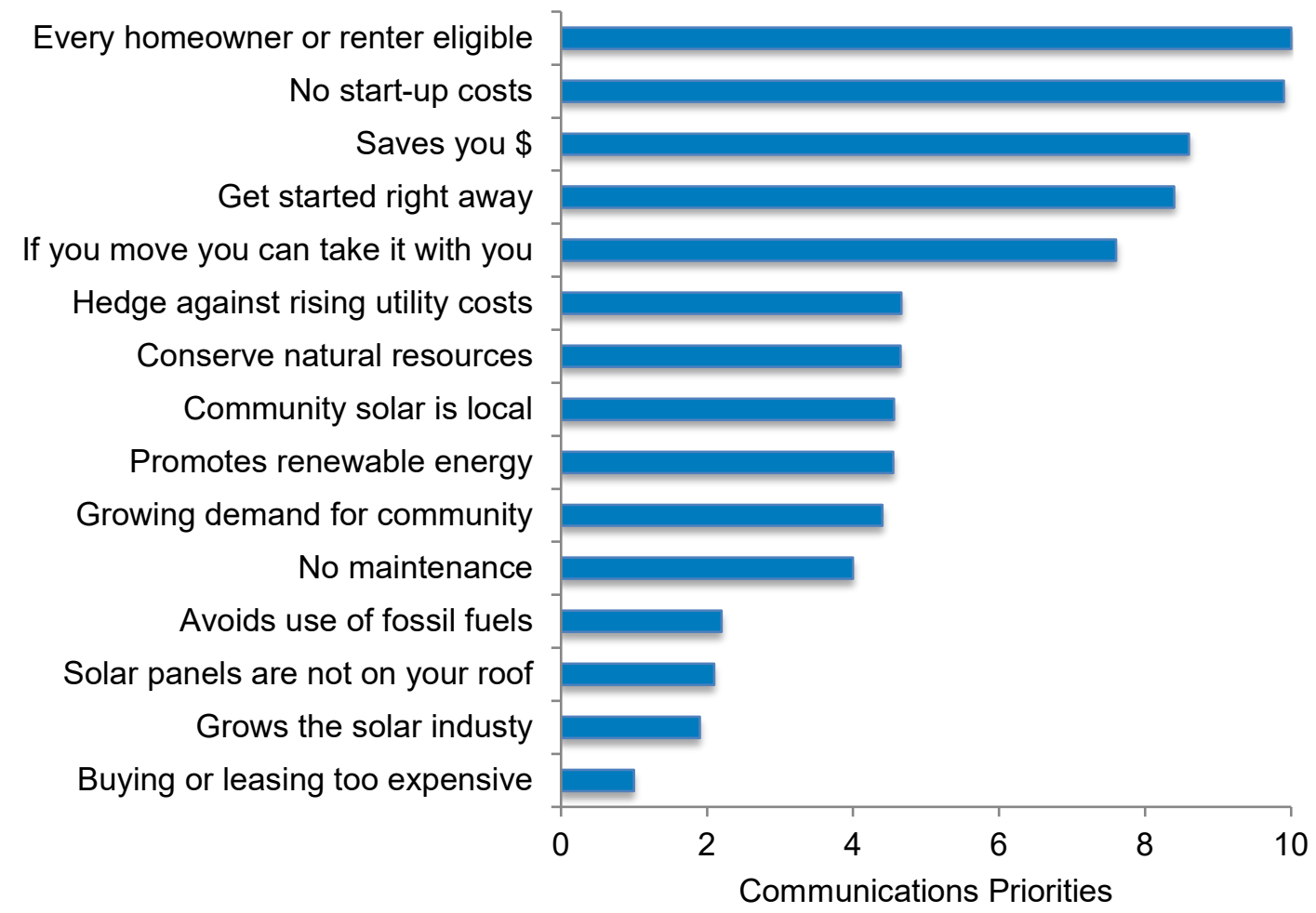

Figure 4. Most compelling messaging for LMI customers based on survey data Source: Pacific Consulting Group 2017

Interviews conducted by NREL with LMI program practitioners resulted in several additional insights about effective messaging strategies, including those described in the rest of this section.

Avoiding Customer Skepticism. LMI customers in particular may be skeptical about opportunities that sound too good to be true. Messaging based only on benefits may increase 
customer skepticism of the program's legitimacy. Instead, messaging should convey benefits and costs. Information that can be useful includes customer's current electricity costs, the customer's subscription cost (even if the program is subsidized), and the value of the customer's bill credits. Messaging with cost information reinforces the program's legitimacy. A clear cost structure reduces perceived risks. With transparent cost structures, customers can see there are no hidden contractual terms that could hurt the customer in the long term. Avoiding customer skepticism can also be addressed by having the messaging come from a known and trusted entity, such as a utility or non-profit organization.

Audience-Specific Messaging. In some cases, it may be best to assume LMI customer bases have lower education levels and tailor a simpler message for LMI customers. Promotional materials could include basic educational information about solar and energy in general. Outreach groups should be prepared to speak languages that are prevalent in local LMI communities and prepare promotional materials in those languages. Outreach efforts should concentrate on local media frequently used by LMI customers (see section 5.4).

Localized Messaging and Pilots. Effective LMI messaging may vary in different contexts. For this reason, several interviewees indicated they are piloting different LMI outreach techniques in local areas to better understand effective marketing approaches. Some programs are using pilot programs to test messaging in certain regions and evaluating results to refine messaging. This approach may help identify effective LMI messaging approaches catered to local nuances.

\subsection{What Are Effective Communications Vehicles?}

Another consideration is distributing messaging and related materials through effective media sources. According to the PCG (2107) survey of LMI customers, the most effective outreach channels are information on the utility bill, followed by more mainstream media channels such as TV and direct mail (see Figure 5).

The cost of outreach is an important consideration, and the need for continued outreach over the duration of the project can be a challenge. For this reason, lower-cost approaches may be required to minimize subscription costs. Language barriers are also a consideration when selecting appropriate communications vehicles.

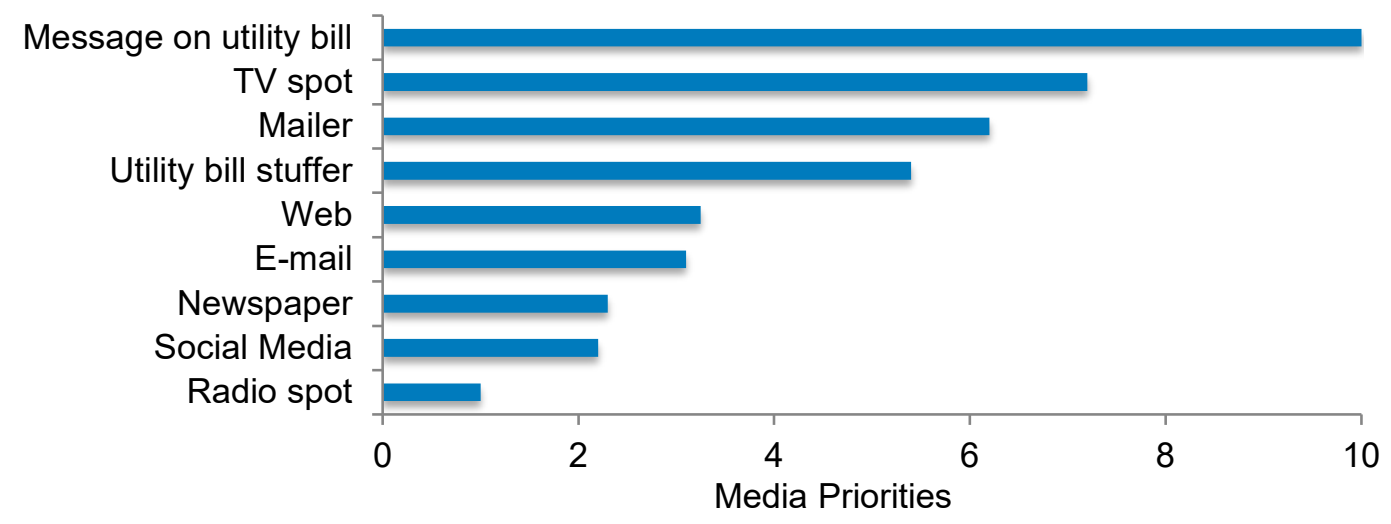

Figure 5. Most effective messaging channels for LMI community solar customers

Source: Pacific Consulting Group 2017 


\section{Summary}

Many states are acting to ensure LMI customers can participate in community solar programs. To date, 11 states and Washington, D.C., have made efforts to expand LMI access to community solar, though programs range widely and are generally in the first stages of implementation. Policymakers developing new LMI community solar programs are considering options related to program design and structure, incentives and financing, and customer outreach.

Program design and structure set the foundation for successful implementation. Key considerations include the following:

- What is the program's goal?

- Will LMI participation be mandated, incentivized, or otherwise supported?

- How might LMI community solar subscriptions be financed or subsidized?

- How will LMI customers be defined?

- Who is responsible for signing up and retaining LMI customers?

- How can customer turnover and default risk be reduced?

- How is billing and crediting handled?

- Where should LMI community solar projects be sited?

For LMI community solar, additional incentives and financing options are often needed to make the program work for LMI customers. While some community solar programs do offer pay-as-you-go options, most require an up-front payment. State policymakers can consider what funding options may be available to address upfront costs and increase bill savings for LMI customers. Policymakers can also work with project developers to create lower-cost project financing options.

Finally, the LMI population can be difficult to reach and skeptical of free or low-cost products. LMI community solar can be effective by partnering with groups that already interact with LMI populations, including utilities, community groups, existing LMI energy programs, and housing authorities. Effective messages include that all renters and homeowners are eligible and what the cost savings potential are. However, the limited experience in LMI community solar suggests that benefits paired with a discussion of costs can facilitate participation, even if the only cost is the time to sign up. 


\section{References}

Baker, Charles D., Karyn E. Polito, Matthew A. Beaton, and Judith Judson. 2017. Solar Massachusetts Renewable Target (SMART): Informational Webinar for Public Entities. Commonwealth of Massachusetts.

https://www.mass.gov/files/documents/2017/04/zl/3-24-17-solar-massachusetts-renewabletarget-slides.pdf.

Barbose, G., N. Darghouth, B. Hoen, and R. Wiser. 2018. Income Trends of Residential PV Adopters: An analysis of household-level income estimates. Berkeley, CA: Lawrence Berkeley National Laboratory. https://emp.lbl.gov/publications/income-trends-residential-pv-adopters

Bovarnick, B., and D. Banks. 2014. State Policies to Increase Low-Income Communities'Access to Solar Power. Center for American Progress.

https:/www.americanprogress.org/issues/green/reports/2014/09/23/97632/state-policies-toincrease-low-income-communities-access-to-solar-power/.

CCSA (Coalition for Community Solar Access). 2017. Community Solar Policy Decision Matrix: Guidance for Designing Community Solar Programs. http://www.communitysolaraccess.org/wp-content/uploads/2017/12/Community-Solar-PolicyDecision-Matrix-2017.pdf.

Colorado Energy Office. 2017. Insights from the Colorado Energy Office Low-Income Community Solar Demonstration Project.

https://www.colorado.gov/pacific/sites/default/files/Insights $\% 20$ from $\% 20$ the $\% 20$ CEO $\% 20$ LowIncome \%20Community\%20Solar\%20Demonstration\%20Project.pdf.

CEAC (Clean Energy Advisory Council). 2017. Report on Alternative Approaches to Providing Low and Moderate Income Clean Energy Services. NYSERDA. http://www3.dps.ny.gov/W/PSCWeb.nsf/All/F287BFCBBA89475885257FCE006D2DBF?Open Document.

CESA (Clean Energy States Alliance). 2017. "Income Verification for Low-Income Solar Programs.” https://www.cesa.org/webinars/income-verification-for-low-income-solarprograms $/$ ?date $=2017-10-13$.

- 2016. A Directory of State Clean Energy Programs and Policies for Low-Income Residents. CESA. http://cesa.org/resource-library/resource/directory-of-state-clean-energyprograms-and-policies-for-low-income-residents.

- 2017. Low-Income Solar, Part 1: Lessons Learned from Low-Income Energy Efficiency Programs. CESA. Webinar: http://www.cleanegroup.org/webinar/low-income-solar-lessonslearned-from-energy-efficiency-programs/.

- 2017. Low-Income Solar, Part 2: Using the Tools of Low-Income Energy Efficiency Financing. CESA. Webinar: http://www.cesa.org/webinars/financing-tools-for-low-incomesolar. 
Chan, C., K. Ernst, and J. Newcomb. 2016. Breaking Ground: New Models that Deliver Energy Solutions to Low-Income Customers. Rocky Mountain Institute.

Connecticut Department of Energy and Environmental Protection. 2017. "DEEP: Shared Clean Energy Pilot Projects Selected.” June 28, 2017.

http://www.ct.gov/deep/cwp/view.asp?A=4918\&Q=594296.

Cook, Jeffrey J. and Monisha Shah. 2018a. Focusing the Sun: State Considerations for Designing Community Solar Policy. Golden, CO: National Renewable Energy Laboratory. NREL/TP-6A20-70663. https://www.nrel.gov/docs/fy18osti/70663.pdf.

Cook, Jeffrey J. and Monisha Shah. 2018b. Reducing Energy Burden with Solar: Colorado's Strategy and Roadmap for States. Golden, CO: National Renewable Energy Laboratory. NREL/ TP-6A20-70965. https://www.nrel.gov/docs/fy18osti/70965.pdf.

DOE (U.S. Department of Energy). 2018. Solar Energy Technologies Office. 2018 Portfolio. https://www.energy.gov/sites/prod/files/2018/02/f48/2018\%20SETO\%20Portfolio\%20Book.pdf

. 2017. The Use of Solar PV in the WAP. WAP Memorandum 024. https://energy.gov/sites/prod/files/2017/01/f34/WAPMEMO\%20024\%201.17.17.pdf.

DOEE (Washington, D.C. Department of Energy and Environment.) 2017. Renewable Portfolio Standard Expansion Amendment Act of 2016 \& Solar for All Annual Report: October 8, 2016September 30, 2017.

https://doee.dc.gov/sites/default/files/dc/sites/ddoe/service_content/attachments/2017\%20Solar\% 20for\%20A11\%20Annual\%20Report.pdf.

EPA (U.S. Environmental Protection Agency). 2017. California Multifamily Affordable Solar Housing Program: Benefitting both owners and tenants. https://www.epa.gov/sites/production/files/2017-06/documents/mash_case_study 6-116 508.pdf.

EPA. 2016. Community Solar: An Opportunity to Enhance Sustainable Development on Landfills and Other Contaminated Sites. https://www.epa.gov/sites/production/files/201612/documents/epa repowering community solar discussion paper final 120716 508.pdf

Federal Register Vol. 81, No. 142, July 25, 2016, p. 48512. https:/www.gpo.gov/fdsys/pkg/FR2016-07-25/pdf/2016-16693.pdf.

Garren, S., A. Giancatarino, S. Greschner, R. Jackson, and I. Schwingler. 2016. Low Income Solar Policy Guide. Center for Social Inclusion. http://www.lowincomesolar.org/.

Gillingham, K., H. Deng, R. Wiser, N. Darghouth, G. Nemet, G. Barbose, V. Rai, and C. Dong. 2016. "Deconstructing Solar Photovoltaic Pricing: The Role of Market Structure, Technology, and Policy." The Energy Journal 37(3): 231-250. 
Go Solar California. n.d. "California Public Utilities Commission Multifamily Affordable Solar Housing Program Handbook."

http://www.gosolarcalifornia.ca.gov/documents/MASH_Handbook.pdf.

GTM. 2017. U.S. Residential Solar PV customer Acquisition 2017: Current and Projected Costs and Channel Strategies. July.

"Community Based Renewable Energy," Hawaii Department of Commerce and Consumer Affairs, http://cca.hawaii.gov/dca/community-based-renewable-energy/.

Douglas Gagne, Alexandra Aznar. 2018. Low-Income Community Solar: Utility Return Considerations for Electric Cooperatives. NREL/TP-7A40-70536.

https://www.nrel.gov/docs/fy18osti/70536.pdf.

Hoffman, I. 2017. "Low- and Moderate-Income Energy Efficiency: Demographics, Challenges, New Approaches," Presentation by LBNL to CESA Webinar, March 23, 2017 http://www.cesa.org/assets/2017-Files/STEP-webinar-slides-3.23.2017.pdf.

Renewable Resources Public Act 99-0906, Illinois Public Service Commission, https://www2.illinois.gov/sites/ipa/Pages/Renewable_Resources.aspx.

IREC (Interstate Renewable Energy Council). 2016. Shared Renewable Energy for Low- to Moderate-Income Consumers: Policy Guidelines and Model Provisions.

Jossi, F. 2017. "Minnesota Community Solar Projects Aimed at Low-Income Subscribers." Energy News Network. https://energynews.us/midwest/minnesota-community-solar-projectsaimed-at-low-income-subscribers/.

Krieger, E., J. Casey, and S. Shonkoff. 2016. "A Framework for Siting and Dispatch of Emerging Energy Resources to Realize Environmental and Health Benefits: Case Study on Peaker Power Plant Displacement." Energy Policy 96: 302-313.

Lotus Engineering and Sustainability, LLC. 2015. Analysis of the Fulfillment of the Low-Income Carve-Out for Community Solar Subscriber Organizations. Prepared for the Colorado Energy Office. November. https://www.colorado.gov/pacific/sites/default/files/atoms/files/CEO\%20LowIncome $\% 20$ Community $\% 20$ Solar\%20Report.pdf.

Mueller, J., and A. Ronen. 2015. Bridging the Solar Income Gap. George Washington Solar Institute.

NDC (National Development Council). 2015. New Markets Tax Credit Project Portfolio. http://ndconline.org/wp-content/uploads/2016/02/NMTC-Portfolio-Web.pdf.

New York Department of Public Service. n.d. "Case 15-E-0751: Value of Distributed Energy Resources (VDER)." http://www3.dps.ny.gov/W/PSCWeb.nsf/All/8A5F3592472A270C8525808800517BDD?OpenD ocument. 
New York Public Service Commission. 2017. “Con Edison's 'Shared Solar' Project for LowIncome Customers Is Approved.” August 2, 2017.

http://www3.dps.ny.gov/pscweb/WebFileRoom.nsf/ArticlesByCategory/33846E2CA4A4F39385 258170005F8469/\$File/pr17060.pdf?OpenElement.

"Low- and Moderate-Income Solar Policy Basics," NREL (National Renewable Energy Lab). 2017, https://www.nrel.gov/technical-assistance/lmi-solar.html.

Ottinger, R., and J. Bowie. 2015. “Innovative Financing for Renewable Energy.” Pace Environmental Law Review 32(3): 701-755.

Paulos, Bentham. 2017. Bringing the Benefits of Solar Energy to Low-Income Customers: A Guide for States and Municipalities. Prepared for the Clean Energy States Alliance. https://www.cesa.org/assets/2017-Files/Bringing-the-Benefits-of-Solar-to-Low-IncomeConsumers.pdf.

PCG (Pacific Consulting Group). 2017. Community Solar for Low Income Customers, SEPA Webinar, Designing and Marketing Community Solar Programs for Low-Income Customers, May 11, 2017.

Public Utility Commission of Oregon. “Order 17-232,” June 29, 2017. http://apps.puc.state.or.us/orders/2017ords/17-232.pdf.

RAP (Regulatory Assistance Project). 2017. Email correspondence with Janine MigdenOstrander and John Shenot. May 26 and May 29, 2017.

Ronen, A., D. Hirsh Bar Gai, and L. Crampton. 2016. Can Electricity Rate Subsidies be Reallocated to Boost Low-Income Solar? George Washington Solar Institute.

Scavo, J., S. Korosec, E. Guerrero, B. Pennington, and P. Doughman. 2016. Low-Income Barriers Study, Part A: Overcoming Barriers to Energy Efficiency and Renewables for LowIncome Customers and Small Business Contracting Opportunities in Disadvantaged Communities. California Energy Commission.

SEIA (Solar Energy Industries Association). 2018. Expanding Solar Availability to the LowIncome Community: Learnings from the Denver Housing Authority. https://www.seia.org/blog/expanding-solar-availability-low-income-community-learningsdenver-housing-authority.

SELC (Southern Environmental Law Center). 2016. Solar For All: What Utilities Can Do Right Now to Bring Solar within Reach for Everyday Folks. SELC.

SEPA (Solar Electric Power Association). 2013. Utility Community Solar Handbook.

_2015. Community Solar Program Design: Working Within the Utility.

—. 2017a. Grand Valley Power's Low-Income Community Solar Program Version 2. 
- 2017b. Designing and Marketing Community Solar Programs for Low-Income Customers. Webinar: https://sepapower.org/media-item/designing-marketing-community-solarprograms-low-income-customers/.

-2017c. Expanding the Scope of Low-Income Solar Program Models.

State of Rhode Island. 2016. "H 8354 Substitute A," June 15, 2016. http://webserver.rilin.state.ri.us/BillText/BillText16/HouseText16/H8354A.pdf.

Treasury (U.S. Department of the Treasury). 2015. Investing in Solar Energy Using the Public Welfare Investment Authority. Community Developments Investments. July. https://www.occ.gov/static/community-affairs/community-developmentsinvestments/solar11/2011-solar-cdezine-final.pdf.

VEIC (Vermont Energy Investment Corporation). 2017. "Sun Shares Demonstrates New Approach to Community Solar." https://www.veic.org/media-room/news/2017/10/05/sun-sharesdemonstrates-new-approach-community-solar.

Wong-Parodi, G., W. Bruine de Bruin, and C. Canfield. 2013. "Effects of Simplifying Outreach Materials for Energy Conservation Programs that Target Low-Income Consumers." Energy Policy 62: 1157-1164.

Xcel Energy. 2016. "2016 Solar RFP." https://www.xcelenergy.com/working_with_us/renewable_developer_resource_center/2017 low income rfp. 


\section{Appendix}

Overview of Existing Programs_Information Current as of May 2018

\begin{tabular}{|c|c|c|c|c|c|}
\hline $\begin{array}{l}\text { State } \\
\text { Program }\end{array}$ & $\begin{array}{l}\text { Program } \\
\text { Status } \\
\text { (Launch } \\
\text { Date) }\end{array}$ & $\begin{array}{l}\text { Program Structure / Capacity Targets } \\
\text { for LMI }\end{array}$ & Customer Eligibility & $\begin{array}{l}\text { Incentives and } \\
\text { Financing }\end{array}$ & $\begin{array}{l}\text { Outreach and } \\
\text { Partnerships }\end{array}$ \\
\hline $\begin{array}{l}\text { California } \\
\text { Solar Initiative } \\
\text { Multifamily } \\
\text { Affordable } \\
\text { Solar Housing }\end{array}$ & $\begin{array}{l}\text { Closed to } \\
\text { new } \\
\text { applications } \\
\text { (2017) }\end{array}$ & $\begin{array}{l}33.75 \mathrm{MW} \text { currently interconnected, and } \\
28 \mathrm{MW} \text { of active reservations. Systems } \\
\text { with virtual net metering and over } 50 \% \text { of } \\
\text { credit directly benefiting tenants receive } \\
\$ 1,800 \text { per kW installed. Rooftop } \\
\text { installations or those with less than } 50 \% \\
\text { directed toward tenant benefit receive } \\
\$ 1,100 \text { per kW installed. }\end{array}$ & $\begin{array}{l}\text { House received financing } \\
\text { from low-income housing tax } \\
\text { credits, tax-exempt mortgage } \\
\text { revenue bonds, general } \\
\text { obligation bonds, or any } \\
\text { government grants. }\end{array}$ & $\begin{array}{l}\text { Financed through state } \\
\text { legislature. Extended by } \\
\$ 108 \text { million and five } \\
\text { years in } 2013 \text {. }\end{array}$ & $\begin{array}{l}\text { Go Solar } \\
\text { California }\end{array}$ \\
\hline $\begin{array}{l}\text { Colorado } \\
\text { Community } \\
\text { Solar Gardens }\end{array}$ & Active (2011) & $\begin{array}{l}5 \% \text { LMI requirement for each individual } \\
\text { community solar array, designated } \\
\text { through rulemaking. }\end{array}$ & \multirow{3}{*}{$\begin{array}{l}\text { Customers must qualify for } \\
\text { LIHEAP or be a member of } \\
\text { Energy Outreach Colorado, } \\
\text { GRID Alternatives, or The } \\
\text { Atmosphere Conservancy. } \\
\text { Municipal housing authorities } \\
\text { are also eligible. }\end{array}$} & $\begin{array}{l}\text { Free subscriptions given } \\
\text { to LMI customers by } \\
\text { developers (costs } \\
\text { presumably passed on } \\
\text { to non-LMI community } \\
\text { solar subscribers). }\end{array}$ & $\begin{array}{l}\text { Denver } \\
\text { Housing } \\
\text { Authority, } \\
\text { Alpine Bank. }\end{array}$ \\
\hline $\begin{array}{l}\text { Colorado Low- } \\
\text { Income } \\
\text { Community } \\
\text { Shared Solar } \\
\text { Demonstration } \\
\text { Project }\end{array}$ & $\begin{array}{l}\text { Closed } \\
(2015)\end{array}$ & $\begin{array}{l}\text { Five demonstration projects (total } 1.5 \\
\text { MW) designed for majority LMI. }\end{array}$ & & $\begin{array}{l}\$ 1.2 \text { million in grant } \\
\text { funding. }\end{array}$ & $\begin{array}{l}\text { GRID } \\
\text { Alternatives. }\end{array}$ \\
\hline $\begin{array}{l}\text { Colorado Xcel } \\
\text { Energy } \\
\text { Settlement }\end{array}$ & $\begin{array}{l}\text { In } \\
\text { development } \\
(2016)\end{array}$ & $\begin{array}{l}13.5 \mathrm{MW} \text { of LMI community solar. } \\
\text { Procured annually (2017-2019) through a } \\
\text { 4-MW RFP, and } 0.5 \mathrm{MW} \text { through } \\
\text { standard offer; Xcel Energy assuming the } \\
5 \% \text { carveout through a new program } \\
\text { (under development). }\end{array}$ & & $\begin{array}{l}\text { REC incentive paid by } \\
\text { ratepayer funds. }\end{array}$ & $\begin{array}{l}\text { To be } \\
\text { determined. }\end{array}$ \\
\hline
\end{tabular}




\begin{tabular}{|c|c|c|c|c|c|}
\hline $\begin{array}{l}\text { State } \\
\text { Program }\end{array}$ & $\begin{array}{l}\text { Program } \\
\text { Status } \\
\text { (Launch } \\
\text { Date) }\end{array}$ & $\begin{array}{l}\text { Program Structure / Capacity Targets } \\
\text { for LMI }\end{array}$ & Customer Eligibility & $\begin{array}{l}\text { Incentives and } \\
\text { Financing }\end{array}$ & $\begin{array}{l}\text { Outreach and } \\
\text { Partnerships }\end{array}$ \\
\hline $\begin{array}{l}\text { Connecticut } \\
\text { Shared Clean } \\
\text { Energy Facility } \\
\text { Pilot Program }\end{array}$ & Pilot (2015) & $\begin{array}{l}\text { Three pilot projects (total } 5.2 \mathrm{MW} \text { ) } \\
\text { selected, each with } 20 \% \text { LMI } \\
\text { participation; Senate Bill } 9 \text { (2018) made } \\
\text { the Shared Clean Energy Facility program } \\
\text { permanent, allowing up to } 25 \mathrm{MW} \text { of } \\
\text { projects per year, with } 10 \% \text { of capacity } \\
\text { towards low-income subscribers, } 10 \% \text { to } \\
\text { LMI or low-income service organizations. }\end{array}$ & $\begin{array}{l}\text { Households, master-metered } \\
\text { households, and affordable } \\
\text { housing building owners are } \\
\text { eligible. }\end{array}$ & $\begin{array}{l}\text { CT Green Bank has } \\
\text { proposed offering lower } \\
\text { interest rates to projects } \\
\text { that provide greater } \\
\text { costs savings to LMI } \\
\text { customers. }\end{array}$ & $\begin{array}{l}\text { Voluntary } \\
\text { partnerships } \\
\text { with CT Green } \\
\text { Bank, } \\
\text { PosiGen. }\end{array}$ \\
\hline $\begin{array}{l}\text { District of } \\
\text { Columbia } \\
\text { Solar For All }\end{array}$ & Active (2016) & $\begin{array}{l}\text { Program to reduce electricity bills of at } \\
\text { least } 100,000 \text { low-income households by } \\
\text { at least } 50 \% \text { (community solar is one } \\
\text { piece of this program). }\end{array}$ & $\begin{array}{l}\text { Low-income defined as } \\
\text { households with below at or } \\
\text { below } 80 \% \text { of area median } \\
\text { income. }\end{array}$ & $\begin{array}{l}\$ 13 \text { million in grants, } \\
\text { initially. }\end{array}$ & $\begin{array}{l}\text { WAP, } \\
\text { Employment } \\
\text { Services, DC } \\
\text { Housing } \\
\text { Authority. }\end{array}$ \\
\hline $\begin{array}{l}\text { Hawaii } \\
\text { Community- } \\
\text { Based } \\
\text { Renewable } \\
\text { Energy }\end{array}$ & $\begin{array}{l}\text { In } \\
\text { development } \\
(2015)\end{array}$ & $\begin{array}{l}50 \% \text { LMI carve-out for } 9 \mathrm{MW} \text { of utility-led } \\
\text { projects. Peak-dispatch incentives } \\
\text { encourage community storage projects. }\end{array}$ & $\begin{array}{l}\text { Utilities and third-party } \\
\text { organizations instructed to } \\
\text { work with state and federal } \\
\text { entities in forming a definition } \\
\text { of verification process. }\end{array}$ & $\begin{array}{l}\text { None now. Funding may } \\
\text { be available from the } \\
\text { Hawaii Green } \\
\text { Infrastructure Authority. }\end{array}$ & $\begin{array}{l}\text { Hawaii's } \\
\text { Public Utilities } \\
\text { Commission } \\
\text { instructs } \\
\text { utilities and } \\
\text { developers to } \\
\text { work with } \\
\text { local } \\
\text { organizations. }\end{array}$ \\
\hline
\end{tabular}




\begin{tabular}{|c|c|c|c|c|c|}
\hline $\begin{array}{l}\text { State } \\
\text { Program }\end{array}$ & $\begin{array}{l}\text { Program } \\
\text { Status } \\
\text { (Launch } \\
\text { Date) }\end{array}$ & $\begin{array}{l}\text { Program Structure / Capacity Targets } \\
\text { for LMI }\end{array}$ & Customer Eligibility & $\begin{array}{l}\text { Incentives and } \\
\text { Financing }\end{array}$ & $\begin{array}{l}\text { Outreach and } \\
\text { Partnerships }\end{array}$ \\
\hline $\begin{array}{l}\text { Illinois } \\
\text { Community } \\
\text { Renewable } \\
\text { Generation } \\
\text { Program }\end{array}$ & $\begin{array}{l}\text { In } \\
\text { development } \\
(2016)\end{array}$ & $\begin{array}{l}\text { The Low-Income Community Solar } \\
\text { Project Initiative provides incentives to } \\
\text { LMI customers; program will also include } \\
\text { Low-Income Community Solar Pilot } \\
\text { Projects. Small subscribers receive an } \\
\text { adder that anchor tenets do not. }\end{array}$ & Not yet determined. & $\begin{array}{l}\text { Guaranteed funding } \\
\text { from ComEd (\$10 } \\
\text { million/year), plus } \\
\text { possible additional } \\
\text { funding from Renewable } \\
\text { Energy Resources Fund } \\
\text { (about } \$ 160 \text { million). } \\
37.5 \% \text { of Solar for All } \\
\text { funds will subsidize LMI } \\
\text { customer for community } \\
\text { solar participation; } \\
22.5 \% \text { of funds will go to } \\
\text { LMI community solar } \\
\text { pilot projects. }\end{array}$ & $\begin{array}{l}\text { Legislation } \\
\text { requires } \\
\text { program } \\
\text { developers to } \\
\text { contract with } \\
\text { third-party } \\
\text { program } \\
\text { administrators } \\
\text { to interface } \\
\text { with LMl } \\
\text { customers, } \\
\text { Pilot Projects } \\
\text { program } \\
\text { requires } \\
\text { partnership } \\
\text { with at least } \\
\text { one } \\
\text { community- } \\
\text { based } \\
\text { organization. }\end{array}$ \\
\hline $\begin{array}{l}\text { Maryland } \\
\text { Community } \\
\text { Solar Energy } \\
\text { Generating } \\
\text { Systems Pilot } \\
\text { Program }\end{array}$ & Pilot (2017) & $\begin{array}{l}60 \mathrm{MW} \text { carve-out for projects where LMI } \\
\text { customers own } 20 \% \text { of output; additional } \\
60 \mathrm{MW} \text { carve-out for "small" projects } \\
\text { including projects with more than } 50 \% \\
\text { LMI participation. }\end{array}$ & $\begin{array}{l}\text { LMI customers at or below } \\
80 \% \text { of federal poverty line or } \\
\text { certified as eligible for bill } \\
\text { assistance from the Maryland } \\
\text { Office of Home Energy } \\
\text { Programs. Operators of low- } \\
\text { income housing may apply as } \\
\text { subscribers. }\end{array}$ & $\begin{array}{l}\text { LMI customers who } \\
\text { subscribe to community } \\
\text { solar under an } \\
\text { ownership model } \\
\text { receive an incentive of } \\
\$ 240 / \mathrm{kW} \text { (compared } \\
\text { with } \$ 80 / \mathrm{kW} \text { for non-LMI } \\
\text { customers). }\end{array}$ & $\begin{array}{l}\text { Works with } \\
\text { existing } \\
\text { programs } \\
\text { (Maryland } \\
\text { Office of } \\
\text { Home Energy } \\
\text { Programs). } \\
\text { Allows for } \\
\text { direct } \\
\text { engagement } \\
\text { with housing } \\
\text { authorities }\end{array}$ \\
\hline
\end{tabular}




\begin{tabular}{|c|c|c|c|c|c|}
\hline $\begin{array}{l}\text { State } \\
\text { Program }\end{array}$ & $\begin{array}{l}\text { Program } \\
\text { Status } \\
\text { (Launch } \\
\text { Date) }\end{array}$ & $\begin{array}{l}\text { Program Structure / Capacity Targets } \\
\text { for LMI }\end{array}$ & Customer Eligibility & $\begin{array}{l}\text { Incentives and } \\
\text { Financing }\end{array}$ & $\begin{array}{l}\text { Outreach and } \\
\text { Partnerships }\end{array}$ \\
\hline $\begin{array}{l}\text { Massachusetts } \\
\text { Virtual Net } \\
\text { Metering }\end{array}$ & $\begin{array}{l}\text { Phasing Out } \\
\text { (2017) }\end{array}$ & $\begin{array}{l}\text { LMI customers are eligible for low-interest } \\
\text { financing from the Mass Solar Loan } \\
\text { program to subsidize community solar } \\
\text { subscriptions }\end{array}$ & $\begin{array}{l}\text { Income-eligible customers, } \\
\text { income eligibility begins at } \\
120 \% \text { of state median } \\
\text { income. Following reform to } \\
\text { net metering in } 2017 \text {, offsite } \\
\text { virtual net metering is valued } \\
\text { at a } 40 \% \text { deduction. }\end{array}$ & $\begin{array}{l}\text { Interest buy-downs by } \\
\text { the Massachusetts } \\
\text { Department of Energy } \\
\text { Resources. }\end{array}$ & None. \\
\hline $\begin{array}{l}\text { Solar } \\
\text { Massachusetts } \\
\text { Renewable } \\
\text { Target } \\
\text { (SMART) }\end{array}$ & $\begin{array}{l}\text { In } \\
\text { development } \\
(2017)\end{array}$ & $\begin{array}{l}1,600 \mathrm{MW} \text { declining block net-metering } \\
\text { program. Community solar serving at } \\
\text { least } 50 \% \text { low-income customers receives } \\
\text { an added } 6 \text { cents/kWh; low income } \\
\text { community solar projects less than } 25 \mathrm{~kW} \\
\text { will receive } 230 \% \text { of the base } \\
\text { compensation rate. }\end{array}$ & $\begin{array}{l}\text { Must be subscribed to an R-2 } \\
\text { rate (low income). } \\
\text { Qualifications for R-2 include } \\
\text { income below } 60 \% \text { of state } \\
\text { median, receiving some form } \\
\text { of benefits, or in public } \\
\text { housing. }\end{array}$ & $\begin{array}{l}\text { Low-income subscribers } \\
\text { receive up to a } \$ 0.06 \text { / } \\
\text { kWh adder. }\end{array}$ & $\begin{array}{l}\text { To be } \\
\text { determined. }\end{array}$ \\
\hline $\begin{array}{l}\text { Minnesota } \\
\text { Community } \\
\text { Solar Gardens }\end{array}$ & Active (2014) & $\begin{array}{l}\text { Utilities required to submit plans for LMI } \\
\text { projects. Xcel's proposal involves } 0.5- \\
\text { MW-1.0-MW dedicated to low-income } \\
\text { customers at no up-front cost. }\end{array}$ & LIHEAP-eligible customers. & $\begin{array}{l}\text { Xcel's LMI pilot would } \\
\text { be free for customers. }\end{array}$ & $\begin{array}{l}\text { Xcel, CENTS } \\
\text { Coalition, } \\
\text { Dayton's Bluff } \\
\text { Neighborhood } \\
\text { Housing } \\
\text { Association, } \\
\text { Center for } \\
\text { Energy and } \\
\text { Environment. }\end{array}$ \\
\hline $\begin{array}{l}\text { New Jersey } \\
\text { Senate Bill }\end{array}$ & $\begin{array}{l}\text { In } \\
\text { development } \\
(2018)\end{array}$ & $\begin{array}{l}\text { The Board of Public Utilities was directed } \\
\text { to develop a community solar pilot } \\
\text { program. The program must provide } \\
\text { access to LMI customers. }\end{array}$ & Not yet determined. & Not yet determined. & $\begin{array}{l}\text { Not yet } \\
\text { determined. }\end{array}$ \\
\hline
\end{tabular}




\begin{tabular}{|c|c|c|c|c|c|}
\hline $\begin{array}{l}\text { State } \\
\text { Program }\end{array}$ & $\begin{array}{l}\text { Program } \\
\text { Status } \\
\text { (Launch } \\
\text { Date) }\end{array}$ & $\begin{array}{l}\text { Program Structure / Capacity Targets } \\
\text { for LMI }\end{array}$ & Customer Eligibility & $\begin{array}{l}\text { Incentives and } \\
\text { Financing }\end{array}$ & $\begin{array}{l}\text { Outreach and } \\
\text { Partnerships }\end{array}$ \\
\hline $\begin{array}{l}\text { New York } \\
\text { State Energy } \\
\text { Research and } \\
\text { Development } \\
\text { Authority } \\
\text { (NYSERDA) } \\
\text { Low Income } \\
\text { Community } \\
\text { Solar Initiative }\end{array}$ & $\begin{array}{l}\text { In } \\
\text { development } \\
(2017)\end{array}$ & $\begin{array}{l}\text { NYSERDA is tasked with introducing an } \\
\text { initiative to provide financial support for } \\
\text { pilot projects, streamline pre-development } \\
\text { assistance, and develop LMI credit and } \\
\text { support mechanisms such as a loan loss } \\
\text { reserve. }\end{array}$ & $\begin{array}{l}\text { Generally, those at or below } \\
60 \% \text { of the state median } \\
\text { income, or otherwise qualified } \\
\text { for the Home Energy } \\
\text { Assistance Program. }\end{array}$ & $\begin{array}{l}\text { The New York Public } \\
\text { Service Commission } \\
\text { backs a proposal to } \\
\text { allow customers } \\
\text { receiving bill assistance } \\
\text { as a credit to apply that } \\
\text { credit toward a } \\
\text { community solar } \\
\text { subscription. }\end{array}$ & NYSERDA. \\
\hline $\begin{array}{l}\text { Oregon } \\
\text { Community } \\
\text { Solar }\end{array}$ & $\begin{array}{l}\text { In } \\
\text { development } \\
(2016)\end{array}$ & $\begin{array}{l}10 \% \text { LMI total, comprised of } 5 \% \\
\text { requirement for each project, along with } \\
5 \% \text { of overall program dedicated to LMI- } \\
\text { only projects. }\end{array}$ & To be determined. & To be determined. & $\begin{array}{l}\text { Outreach was } \\
\text { not mandated } \\
\text { by legislation. }\end{array}$ \\
\hline $\begin{array}{l}\text { Rhode Island } \\
\text { Community } \\
\text { Remote Net } \\
\text { Metering }\end{array}$ & Active (2016) & $\begin{array}{l}\text { No specific LMI requirement. Developer } \\
\text { offtakers required to provide "tangible } \\
\text { benefits" to their LMI tenants. }\end{array}$ & $\begin{array}{l}\text { Program designed to allow } \\
\text { affordable housing building } \\
\text { owners to participate }\end{array}$ & $\begin{array}{l}\$ 200 \text { LMI customer } \\
\text { acquisition subsidy to } \\
\text { defray costs (must be } \\
\text { passed through to } \\
\text { customer) }\end{array}$ & $\begin{array}{l}\text { Rhode Island } \\
\text { Housing } \\
\text { involved in } \\
\text { rulemaking } \\
\text { process. }\end{array}$ \\
\hline
\end{tabular}




\section{List of Community Solar Developers}

Note: This list is not exhaustive and is for informational purposes only.

\section{Community Solar Only}

- Clean Energy Collective

- Community Solar

- Soveren Solar

- Sunshare

Solar Developers with Community Solar Experience

- Able Energy

- Ameresco

- Arcadia Power

- BlueWave

- Community Energy Solar

- Ecoplexus

- IGS Generation

- Innovative Power Systems

- Nexamp

- Next Step Living

- Novel Energy Solutions

- NRG

- Renovus Solar

- SoCore Energy

- SolarStone

- Solar Synergy

- Spear Point Energy

- Sundial Solar

- Sunrise

- Suntility

- Syncarpha

- Tangerine Power

- TruNorth Solar

\section{Low-Income Solar Specialists}

- Grid Alternatives

- Posigen 